\title{
Tuyển sinh đại học ngành Việt Nam Học 2015
}

Faculty of Vietnamese Studies

09 April 2015

University of Social Sciences and Humanities

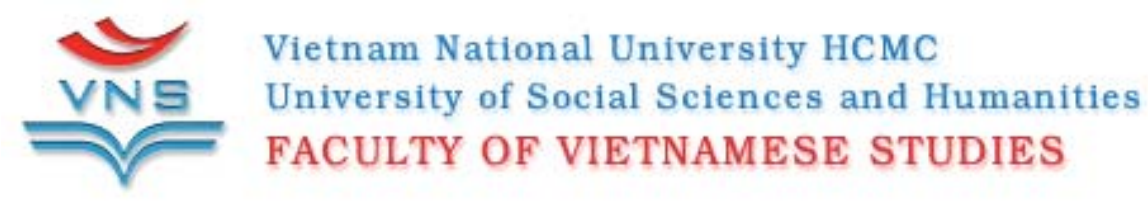

Vietnam National University HCMC

http://vns.edu.vn/v1/index.php/en/vietnamese-studies/undergraduate-program/course-examresults/550-tuyn-sinh-i-hc-nganh-vit-nam-hc-2015 


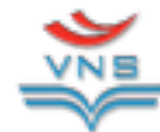

舟:

The Bachelor Programme of Vietnamese Studies has successfully completed the AUN - QA standards

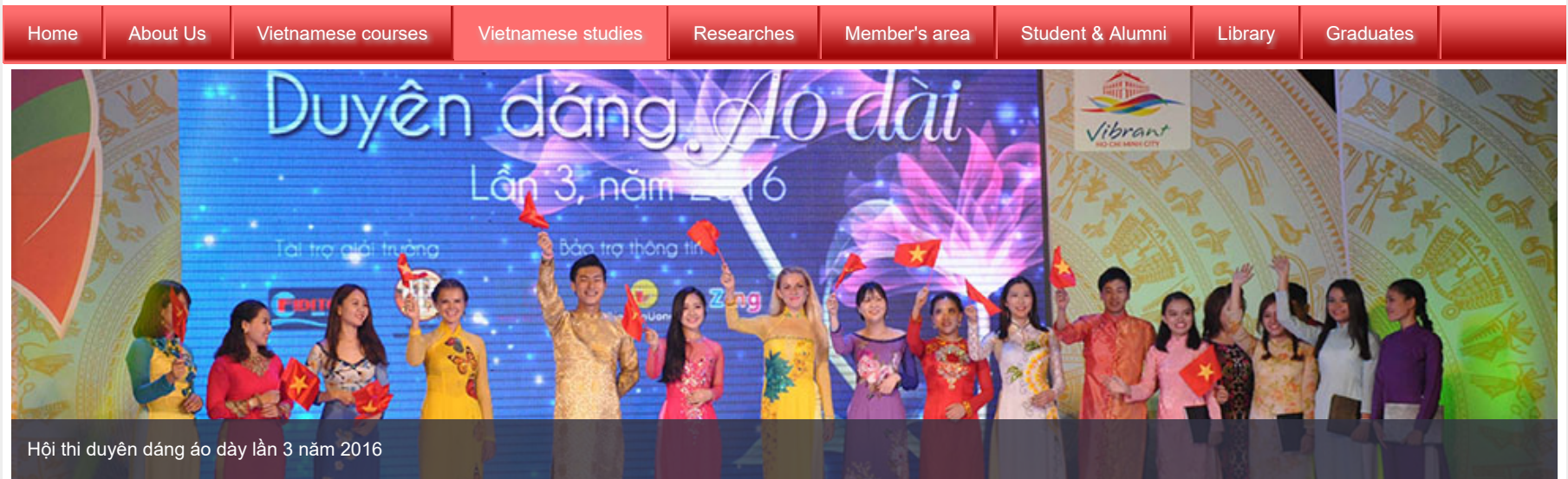

VIETNAMESE STUDIES

+ Undergraduate Program
B.A In Vietnamese Studies
Twin Program
3+1 Program
Course Exam Results
B.A In Online Vietnamese
Studies
+ Praduate Program
+ Cultural Program
+ Chương trình Tiến sĩ
" Forms
" Guideline

Tuyển sinh đại học ngành Việt Nam Học 2015

Thursday, 09 April 2015 Category: Course Exam Results - 블

TP. Hồ Chí Minh, ngày 1 tháng 4 năm 2015

\section{CHƯƠNG TRÌNH GIÁO DỤC ĐẠI HỌC}

- Tên chương trình: Chương trình đào tạo bậc đại học ngành Việt Nam học

\author{
- Trình độ đào tạo: Đại học \\ - Ngành đào tạo: Việt Nam học \\ - Loại hình đào tạo: Chính quy \\ - Mã ngành đào tạo: 52.22.01.06
}

- Trưởng nhóm dự án: PGS.TS. Lê Khắc Cường

\subsection{Mục tiêu chung}

Chương trình đào tạo ngành Việt Nam học bậc đại học là chương trình đào tạo dành cho đối tượng sinh viên là Việt kiều và người nước ngoài, hướng đến đào tạo những cử nhân có kiến thức chuyên môn vững, kỹ năng thuần thục, có tinh thần, thái độ phục vụ tốt, đáp ứng ở mức độ cao yêu cầu của công việc liên quan đến đất nước, con người Việt Nam. Chương trình đào tạo được thiết kế với mục tiêu:

- Trang bị cho sinh viên những kiến thức nền tảng về khoa học xã hội và nhân văn.

- Trang bị cho sinh viên những kiến thức cở bản, hiện đại về đất nước, con người Việt Nam.

- Trang bị cho sinh viên những kiến thức cơ bản về cơ cấu tiếng Việt.

- Rèn luyện và phát triển khả năng vận dụng lý thuyết liên quan vào thực tiễn nghề nghiệp cho sinh viên.

- Rèn luyện và phát triển cho sinh viên các kỹ năng làm việc cơ bản.

1.2. Chuẩn đầu ra của chương trình đào tạo

1.2.1. Trình độ kiến thức

Cử nhân ngành Việt Nam học được trang bị có hệ thống các khối kiến thức sau:

- Những kiến thức nền tảng về khoa học xã hội và hành vi, tạo cơ sở để sinh viên học tập, nghiên cứu Việt Nam học;

- Những kiến thức cơ bản, hiện đại về đất nước, con người Việt Nam (lịch sử, văn hoá, xã hội, ngôn ngữ, văn học, kinh tế, chính trị);

- Những kiến thức cơ bản về cơ cấu tiếng Việt (ngữ âm, từ vựng, ngữ pháp); một số lượng có chọn lọc về từ vựng và quy tắc ngữ pháp đủ để sinh viên hoàn thiện 4 kỹ năng nghe - nói - đọc - viết tiếng Việt. 
- Kiến thức bổ trợ: Tin học văn phòng, viết, biên tập văn bản,...

\subsubsection{Năng lực nhận thức, tư duy/kỹ năng thực hành}

Cử nhân ngành Việt Nam học được đào tạo để đáp ứng đáp ở mức độc cao nhu cầu của thị trường lao động. Cử nhân ngành Việt Nam học:

- Biết vận dụng những kiến thức cơ bản, hiện đại về Việt Nam học vào các công việc cụ thể;

- Sử dụng thông thạo tiếng Việt (nói và viết) trong các tình huống giao tiếp khác nhau (trang trọng, thân mật...), trong công tác phiên dịch, biên dịch; có khả năng giao tiếp hiệu quả.

- Có khả năng làm việc nhóm và làm việc trong tổ chức, đặc biệt là với nhóm/tổ chức có người Việt Nam.

- Sinh viên nước ngoài và Việt kiều khi tốt nghiệp có khả năng sử dụng thông thạo tiếng Việt trong công tác và cuộc sống hàng ngày trong các tình huống giao tiếp khác nhau (trang trọng, thân mật,...)

\subsubsection{Phẩm chất nhân văn}

Cử nhân ngành Việt Nam học được đào tạo vừa hồng vừa chuyên, có tri thức vững vàng và những phẩm chất nhân văn tốt đẹp:

- Có được nền tảng giáo dục vững chắc để hiểu được trách nhiệm của một công dân, trách nhiệm đối với nghề nghiệp, trách nhiệm với cộng đồng xã hội và bản thân.

1.2.4 Vị trí việc làm và cơ hội học lên trình độ cao hơn

\section{Vị trí làm việc}

Cử nhân ngành Việt Nam học có thể làm công tác giảng dạy, nghiên cứu tiếng Việt tại các trường đại học, cao đẳng trung học phổ thông tại chính quốc hoặc tại các cơ sở giáo dục có trường sở tại Việt Nam; làm công tác biên - phiên dịch tiếng Việt trong các cơ quan kinh tế, ngoại giao, giáo dục, truyền thông của nước ngoài; làm hướng dẫn viên du lịch,...

\section{Cơ hội học lên cao hơn}

Cử nhân ngành Việt Nam học có thể tiếp tục học bậc sau đại học (thạc sĩ, tiến sĩ) chuyên ngành Việt Nam học hoặc các chuyên ngành gần như Ngôn ngữ học, Văn hoá học, Lịch sử Việt Nam, Nhân học,...

\subsection{Ma trân tương quan giữa mục tiêu đào tạo, chuẩn đầu ra và môn học}

\subsubsection{Ma trận giữa mục tiêu đào tạo và các học phần}

\begin{tabular}{|c|c|}
\hline Mục tiêu đào tạo (M) & Các học phần trong CTĐT \\
\hline $\begin{array}{l}\text { M1. Trang bị cho sinh viên } \\
\text { những kiến thức nền tảng về } \\
\text { khoa học xã hội, nhân văn. }\end{array}$ & $\begin{array}{l}\text {-Những_nguyên lý_cơ bản của CN Mác- } \\
\text { Lênin } \\
\text { - Đường lối cách mạng_của ĐCS Việt Nam } \\
\text { - Tư tưởng Hồ Chí Minh } \\
\text { - Môi trường và phát triển } \\
\text { - Lịch sử văn minh thế giới } \\
\text { - Địa lý và cư dân các nước Đông Nam Á } \\
\text { - Tiến trình lịch sử Việt Nam } \\
\text { - Cơ sở văn hoá Việt Nam } \\
\text { - Khảo cổ học Việt Nam } \\
\text { - Kinh tế học đại cương } \\
\text { - Lôgich học đại cương } \\
\text { - Xã hội học đại cương } \\
\text { - Văn minh Đông Nam Á } \\
\text { - Thống kê cho khoa học xã họi } \\
\text { - Kinh tế học đại cương } \\
\text { - Dẫn luận ngôn ngữ học } \\
\text { - Nhân học đại cương } \\
\text { - Tâm lý học đại cương } \\
\text { - Tôn giáo học đại cương } \\
\text { - Pháp luật đại cương } \\
\text { - Chính trị học đại cương }\end{array}$ \\
\hline $\begin{array}{l}\text { M2. Trang bị cho sinh viên } \\
\text { những kiến thức cơ bản, hiện } \\
\text { đại về đất nước, con người Việt } \\
\text { Nam. }\end{array}$ & $\begin{array}{l}\text { - Nhập môn khu vực học và Việt Nam học } \\
\text { - ASEAN và quan hêe Việt Nam - ASEAN } \\
\text { - Văn hoá bảo đảm đời sống của người Việt } \\
\text { - Văn hoá ứng xử Việt Nam } \\
\text { - Các dân tộc ít người ở Việt Nam }\end{array}$ \\
\hline
\end{tabular}




\begin{tabular}{|c|c|}
\hline Mục tiêu đào tạo (M) & Các học phần trong CTĐT \\
\hline & $\begin{array}{l}\text { - Kinh tế Việt Nam } \\
\text { - Hệ thống chính trị Việt Nam hiện đại } \\
\text { - Văn hoá du lị̣ch Việt Nam } \\
\text { - Địa lý Việt Nam: tự nhiên, nhân văn, kinh tế } \\
\text { - Các tôn giáo ở Việt Nam } \\
\text { - Làng xã Việt Nam } \\
\text { - Các đặc trưng sinh thái môi trường Việt } \\
\text { Nam } \\
\text { - Đại cương văn học Việt Nam } \\
\text { - Văn học dân gian Việt Nam } \\
\text { - Truyện ngắn Việt Nam hiện đại }\end{array}$ \\
\hline $\begin{array}{l}\text { Mus. Trang bị cho sinh viên } \\
\text { ngươ̛i nước ngoài những kiến } \\
\text { thức cơ bản và chuẩn mực về } \\
\text { tiếng Việt }\end{array}$ & $\begin{array}{l}\text { - Lịch sử tiếng Việt } \\
\text { - Các hệ ngôn ngữ ở Việt Nam } \\
\text { - Tiếng Việt trung cấp, nâng cao, học thuật } \\
\text { - Ngữu pháp, ngữ âm, từ vựng tiếng Việt } \\
\text { - Phương_ngữu tiếng Việt } \\
\text { - Phong cách học tiếng Việt } \\
\text { - Từ Hán - Việt } \\
\text { - Tiếng Việt báo chí, tiếng Việt thương mại } \\
\text { - Ngôn ngữ học đối chiếu }\end{array}$ \\
\hline $\begin{array}{l}\text { M4. Rèn luyêen và phát triển khả } \\
\text { năng vận dụnglý thuyết liên } \\
\text { quan vào thực tiễn nghề nghiệp; } \\
\text { rèn luyêen và phát triển cho sinh } \\
\text { viên các kỹ năng làm việc cơ } \\
\text { bản. }\end{array}$ & $\begin{array}{l}\text { - Phương_pháp học đại học } \\
\text { - Phương_pháp nghiên cứu khoa học } \\
\text { - Phương_phápgiảng_dayyngoại ngữ } \\
\text { - Lý thuyết dịch } \\
\text { - Ngôn ngữ học đối chiếu } \\
\text { - Các phương tiên liên kết và soạn thảo văn } \\
\text { bản tiếng Việt } \\
\text { - Lôgich học đại cương } \\
\text {-Tâm lý học đại cương } \\
\text { - Pháp luật đại cương } \\
\text { - Thống kê cho khoa học xã hội } \\
\text { - Thực tập tốt nghiệp } \\
\text { - Khoá luận tốt nghiệp }\end{array}$ \\
\hline $\begin{array}{l}\text { M5. Trang bị cho sinh viên } \\
\text { ngoại ngữú } 2 \text { (tiếng Việt) và kiến } \\
\text { thức tin học để sử dụng trong } \\
\text { đời sống, công tác }\end{array}$ & $\begin{array}{l}\text { - Tin học căn bản } \\
\text { - Ngoại ngữ } 2 \text { (tiếng Việt) }\end{array}$ \\
\hline
\end{tabular}

\subsubsection{Ma trận giữa mục tiêu đào tạo và chuẩn đầu ra của CTĐT}

\begin{tabular}{|c|c|c|c|}
\hline \multicolumn{2}{|r|}{ Mục tiêu đào tạo } & \multicolumn{2}{|r|}{ Chuẩn đầu ra của CTĐT } \\
\hline M1 & $\begin{array}{l}\text { Trang_bị cho sinh viên } \\
\text { những kiến thức nền } \\
\text { tảng về khoa học xã hôi } \\
\text { và nhân văn. }\end{array}$ & $\underline{\mathrm{C} 1}$ & $\begin{array}{l}\text { Sinh viên tốt nghiệp nắm vững những } \\
\text { kiến thức nền tảng về khoa học xã hội } \\
\text { và nhân văn. }\end{array}$ \\
\hline M2 & $\begin{array}{l}\text { Cung cấp cho sinh viên } \\
\text { những kiến thức cơ } \\
\text { bản, hê thống, hiện đại } \\
\text { và thiết thực về đất } \\
\text { nước, con người Việt } \\
\text { Nam. }\end{array}$ & $\underline{\mathrm{C} 2}$ & $\begin{array}{l}\text { Sinh viên tốt nghiệp nắm vững những } \\
\text { kiến thức cơ bản, hiện đại về đất } \\
\text { nước, con người Việt Nam (lịch sứ, } \\
\text { văn hoá, xã hội, văn học, kinh tế, } \\
\text { chính trị); }\end{array}$ \\
\hline M3 & $\begin{array}{l}\text { Trang_bị cho sinh viên } \\
\text { những kiến thức cơ bản } \\
\text { về cơ cấu tiếng Việt. }\end{array}$ & $\underline{\mathrm{C} 3}$ & $\begin{array}{l}\text { Sinh viên tốt nghiệp nắm vững những } \\
\text { kiến thức cơ bản về cơ cấu tiếng Việt } \\
\text { (ngữ âm, từ vựng, ngữ pháp). } \\
\text { Sinh viên tốt nghiệp có khả năng_sử } \\
\text { dunng thông thao tiếng Việt trong trong } \\
\text { công tác và cuộc sống sinh hoạt hàng }\end{array}$ \\
\hline
\end{tabular}

M․ Trang bị cho sinh viên tiếng Việt
- Lịch sử tiêng Việ

- Tiếng Việt trung cấp, nâng cao, học thuật

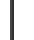 (2)} .

Phươngngữu tiếng Viêt

- Phong cách học tiếng Việt

- Từ Hán - Việt

- Tiếng Việt báo chí, tiếng Việt thương mại

- Phương_pháp học đại học

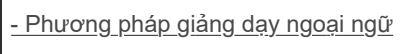

- Các phương tiên liên kết và soạn thảo văn

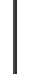

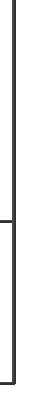

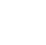




\begin{tabular}{|c|c|c|c|}
\hline \multicolumn{2}{|r|}{ Mục tiêu đào tạo } & \multicolumn{2}{|r|}{ Chuẩn đầu ra của CTĐT } \\
\hline & & & $\begin{array}{l}\text { ngày trong_các tình huống_giao tiếp } \\
\text { khác nhau (trang trong, thân mâat...). }\end{array}$ \\
\hline M44 & $\begin{array}{l}\text { Rèn luyện và phát triển } \\
\text { cho sinh viên khả năng } \\
\text { vận dụng_lý thuyết liên } \\
\text { quan vào thực tiễn nghề } \\
\text { nghiệp; Rèn luyêen và } \\
\text { phát triển cho sinh viên } \\
\text { các kỹ năng làm việc cơ } \\
\text { bản. }\end{array}$ & $\underline{\mathrm{C}} 4$ & $\begin{array}{l}\text { Áp dụng được những kiến thức } \\
\text { bản, hiện đại về Việt Nam học vào } \\
\text { thực tiễn nghề nghiệp; } \\
\text { Có khả năng_giao tiếp xã hội hiệu quả. } \\
\text { Có khả năng làm việc nhóm và làm } \\
\text { việc trong một tổ chức, đặc biệt là với } \\
\text { nhóm/tổ chức có người Việt Nam. } \\
\text { Có thái độ đúng mực, tích cực, khoa } \\
\text { học. }\end{array}$ \\
\hline M5 & $\begin{array}{l}\text { Trang_bị cho sinh viên } \\
\text { ngoaai ngữ } 2 \text { (tiếng Việt) } \\
\text { và kiến thức tin học để } \\
\text { sử dụng_trong đời sống, } \\
\text { công_tác }\end{array}$ & $\underline{\mathbf{C}} 5$ & $\begin{array}{l}\text { Sinh viên tốt nghiệp sử dụng được } \\
\text { tiếng Việt trong_giao tiếp, nghiên cức } \\
\text { sinh viên phải đạt trình độ tin học văn } \\
\text { phòng (chứng chỉ tin học A hoặc tin } \\
\text { học văn phòng). }\end{array}$ \\
\hline
\end{tabular}

1.3.3 Ma trận giữa các học phần và chuẩn đầu ra của CTĐT

\begin{tabular}{|c|c|c|c|c|c|c|c|}
\hline \multirow[t]{2}{*}{$\underline{\text { TT }}$} & \multirow[t]{2}{*}{ Mã MH } & \multirow[t]{2}{*}{ Tên môn học } & \multicolumn{5}{|c|}{ Chuẩn đầu ra1 } \\
\hline & & & $\underline{\mathrm{C} 1}$ & $\underline{\mathrm{C} 2}$ & $\underline{\mathrm{C} 3}$ & $\underline{\mathrm{C}} 4$ & $\underline{\mathbf{C}} 5$ \\
\hline 1 & DAI001 & $\begin{array}{l}\text { Những nguuyên lý_cơ bản của } \\
\text { CN Mác-Lênin I }\end{array}$ & 2 & 2 & & & \\
\hline$\underline{2}$ & DAI002 & $\begin{array}{l}\text { Những nguyên lý_cơ bản của } \\
\text { CNN Mác-Lênin II }\end{array}$ & 2 & 2 & & & \\
\hline$\underline{3}$ & DAI003 & $\begin{array}{l}\text { Đường_lối cách mạng_của } \\
\text { ĐCS Việt Nam }\end{array}$ & $\underline{2}$ & 2 & & & \\
\hline$\underline{4}$ & DAI004 & Tư tưởng Hồ Chí Minh & $\underline{2}$ & 2 & & & \\
\hline$\underline{5}$ & DAI005 & Thống kê cho khoa học xã hội & $\underline{2}$ & & & $\underline{2}$ & \\
\hline$\underline{6}$ & DAI006 & Môi trường và phát triển & $\underline{2}$ & 1 & & & \\
\hline 7 & DAI012 & Cơ sở văn hoá Việt Nam & 2 & 2 & & 1 & \\
\hline 8 & DAI013 & Dẫn luận Ngôn ngữ học & 1 & & 1 & & \\
\hline 9 & DAI016 & Lị̣ch sử văn minh thế giới & 2 & 1 & & & \\
\hline 10 & DAI017 & Tiến trình lịch sử Viêt Nam & $\underline{2}$ & $\underline{2}$ & & & \\
\hline 11 & DAI021 & Lôgich học đại cương & 1 & & & 1 & \\
\hline 12 & DAI022 & Xã hội học đại cương & 2 & 1 & & 1 & \\
\hline 13 & DAI027 & Kinh tế học đại cương & 1 & 1 & & & \\
\hline 14 & DAI036 & $\begin{array}{l}\text { Phương_pháp_nghiên cứu } \\
\text { khoa học }\end{array}$ & 2 & & & 2 & \\
\hline 15 & VNH018 & Phương pháp học đại học & 2 & & & 2 & \\
\hline 16 & DAI023 & Tâm lý học đại cương & 1 & 1 & & 1 & \\
\hline 17 & DAI024 & Nhân học đại cương & 1 & 1 & & 1 & \\
\hline 18 & DAI025 & Pháp luật đại cương & 2 & 2 & & 1 & \\
\hline 19 & DAI029 & Chính trị học đại cương & 1 & 1 & & & \\
\hline 20 & DAI030 & Tôn giáo học đại cương & 1 & 1 & & & \\
\hline 21 & DAI048 & Tin học đại cương 3 & & & & & $\underline{3}$ \\
\hline
\end{tabular}
Có khả năng_giao tiếp xã hội hiệu quả tiếng Việt trong_giao tiếp, nghiên cứu; phòng (chứng chỉ tin học $\mathrm{A}$ hoặc tin hoc văn phòng).

$$
\text { . }
$$

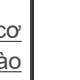

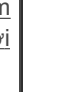

ngày trong các tình huống_giao tiếp

Áp dụng được những kiến thức bản, hiện đại về Việt Nam học vào 


\begin{tabular}{|c|c|c|c|c|c|c|c|}
\hline \multirow[t]{2}{*}{ TT } & \multirow[t]{2}{*}{$\underline{\text { Mã MH }}$} & \multirow[t]{2}{*}{ Tên môn học } & \multicolumn{5}{|c|}{ Chuẩn đầu ra1 } \\
\hline & & & c1 & $\underline{\mathrm{c} 2}$ & $\underline{\mathrm{C} 3}$ & $\underline{\mathrm{C}} 4$ & C5 \\
\hline 22 & VNH023 & Tiếng Việt trung cấp: Nói & & & 3 & 2 & 3 \\
\hline 23 & VNH022 & Tiếng Việt trung cấp: Nghe & & & 3 & 2 & 3 \\
\hline 24 & VNH021 & Tiếng Việt trung cấp: Đọc & & & 3 & 2 & 3 \\
\hline 25 & VNH024 & Tiếng Việt trung cấp: Viết & & & 3 & 2 & 3 \\
\hline 26 & VNH021 & Tiếng Việt trung cấp: Đọc & & & 3 & 2 & 3 \\
\hline 27 & VNH022 & Tiếng Việt trung cấp: Nghe & & & 3 & 2 & 3 \\
\hline 28 & VNH023 & Tiếng Việt trung cấp: Nói & & & 3 & 2 & 3 \\
\hline 29 & VNH024 & Tiếng Việt trung cấp: Viết & & & 3 & 2 & 3 \\
\hline 30 & VNH030 & Tiếng Việt nâng cao: Đọc & & & 3 & 2 & 3 \\
\hline 31 & VNH031 & Tiếng Việt nâng cao: Nghe & & & 3 & 2 & 3 \\
\hline 32 & VNH032 & Tiếng Việt nâng cao: Nói & & & 3 & 2 & 3 \\
\hline 33 & VNH033 & Tiếng Việt nâng cao: Viết & & & 3 & 2 & 3 \\
\hline 34 & VNH025 & Tiếng Việt học thuật: Đọc & & & 3 & 2 & 3 \\
\hline 35 & VNH026 & Tiếng Việt học thuật: Nghe & & & 3 & 2 & 3 \\
\hline 36 & VNH027 & Tiếng Việt học thuật: Nói & & & 3 & 2 & 3 \\
\hline 37 & VNH028 & Tiếng Việt học thuật: Viết & & & 3 & 2 & 3 \\
\hline 38 & VNH015 & $\begin{array}{l}\text { Nhâp môn khu vực học và Việt } \\
\text { Nam học }\end{array}$ & 2 & 3 & & & \\
\hline 39 & $\underline{\mathrm{VNH}} 040$ & Kinh tế Việt Nam & 1 & 2 & & & \\
\hline 40 & VNH041 & $\begin{array}{l}\text { Hệ thống chính trị Việt Nam } \\
\text { hiện đại }\end{array}$ & 1 & 2 & & & \\
\hline 41 & VNH009 & $\begin{array}{l}\text { Địa lý Việt Nam: tự nhiên-nhân } \\
\text { văn-kinh tế }\end{array}$ & 1 & 2 & & & \\
\hline 42 & VNH006 & Đại cương văn học Việt Nam & 1 & 3 & & 2 & \\
\hline 43 & VNH013 & Ngữ pháp tiếng Việt & 1 & & $\underline{3}$ & 2 & \\
\hline 44 & DAI014 & Ngôn ngữ học đối chiếu & & & 1 & & \\
\hline 45 & VNH004 & $\begin{array}{l}\text { Các phương tiện liên kết và } \\
\text { soan thảo văn bản tiếng Việt }\end{array}$ & & & 2 & & \\
\hline 46 & $\underline{\mathrm{VNH} 036}$ & Văn hoá du lịch Việt Nam & 2 & 2 & & & \\
\hline 47 & $\underline{\text { LSU065 }}$ & Khảo cổ học Việt Nam & 1 & 1 & & & \\
\hline
\end{tabular}




\begin{tabular}{|c|c|c|c|c|c|c|c|}
\hline \multirow[t]{2}{*}{$\underline{\text { TT }}$} & \multirow[t]{2}{*}{ Mã MH } & \multirow[t]{2}{*}{ Tên môn học } & \multicolumn{5}{|c|}{ Chuẩn đầu ra1 } \\
\hline & & & $\underline{\text { c1 }}$ & $\underline{\mathrm{C} 2}$ & c3 3 & $\underline{\mathrm{C}} 4$ & $\underline{\mathrm{C}} 5$ \\
\hline 48 & VNH038 & Văn minh Đông Nam Á & 1 & 1 & & & \\
\hline 49 & VNH001 & $\begin{array}{l}\text { ASEAN và Quan hệ VN } \\
\text {-ASEAN }\end{array}$ & 1 & 1 & & & \\
\hline 50 & VNH008 & $\begin{array}{l}\text { Địa lýy và cư dân các nước } \\
\text { Đông Nam } A \dot{A}\end{array}$ & 2 & 2 & & & \\
\hline 51 & VNH002 & $\begin{array}{l}\text { Các đăc trung_sinh thái môi } \\
\text { trường VN }\end{array}$ & 1 & 1 & & & \\
\hline 52 & VNH035 & $\begin{array}{l}\text { Văn hoá bảo đảm đời sống ở } \\
\text { Việt Nam }\end{array}$ & 2 & 2 & & & \\
\hline 53 & VNH037 & Văn hoá ứng xử Việt Nam & $\underline{2}$ & $\underline{2}$ & & & \\
\hline 54 & VNH039 & Các dân tộc ở Việt Nam & 1 & 1 & & & \\
\hline 55 & VNH005 & Các tôn giáo ở Việt Nam & 2 & 2 & 1 & & \\
\hline 56 & VNH012 & Ngữ âm tiếng Việt thực hành & & & 1 & & \\
\hline 57 & VNH034 & Từ vựng tiếng Việt thực hành & & & 1 & & \\
\hline 58 & VNH003 & Các hệngôn ngữu ở Việt Nam & & & $\underline{2}$ & & \\
\hline 59 & VNH011 & Lyý thuyết dịch & & & 1 & & \\
\hline 60 & DAI039 & Lịch sử tiếng Việt & & & 1 & & \\
\hline 61 & VNH016 & Phương_ngữ tiếng Việt & & & 1 & & \\
\hline 62 & VNH044 & Phong cách học tiếng Việt & & & 1 & & \\
\hline 63 & VNH045 & Từ Hán - Việt & & & 1 & & \\
\hline 64 & VNH046 & Văn học dân gian Việt Nam & 1 & 2 & & & \\
\hline 65 & VNH017 & $\begin{array}{l}\text { Phương_pháp giảng dạy ngoại } \\
\underline{\text { ngụ̂u }}\end{array}$ & & 1 & & 1 & \\
\hline 66 & VNH047 & Truyện ngắn Việt Nam hiện đại & & 1 & 1 & & \\
\hline 67 & VNH020 & Tiếng Việt báo chí & & 1 & 1 & 1 & \\
\hline 68 & VNH029 & Tiếng Viêt thương mai & & 1 & 1 & & \\
\hline 69 & DAI014 & Ngôn ngữ học đối chiếu & & & 1 & 1 & \\
\hline 70 & VNH019 & Thực tập tốt nghiêpp & $\underline{3}$ & $\underline{3}$ & $\underline{3}$ & $\underline{2}$ & $\underline{2}$ \\
\hline 71 & VNH010 & Khoá luận tốt nghiêpp & & & & 2 & 2 \\
\hline
\end{tabular}

\section{Thời gian đào tạo}

Chương trình cử nhân ngành Việt Nam học cho sinh viên người nước ngoài được đào tạo với thời gian chuẩn là 4 (bốn) năm. Tuy nhiên, tuỳ theo khả năng học tập, sinh viên có thể rút ngắn thời gian học tập tối đa 1 (một) học kỳ chính hoặc có thể kéo dài thời gian học tối đa là 4 (bốn) học kỳ chính (tương đương từ 3,5 (ba năm rưỡi) năm đến 6 (sáu) năm).

Quy chế đào tạo: Chương trình giáo dục đại học ngành Việt Nam học được tổ chức dựa theo các văn bản sau:

- "Quy chế đào tạo đại học và Cao đẳng hệ chính quy theo hệ thống tín chỉ" được ban hành theo Quyết định số 43/2007 /QĐ-BGD\&ĐT ngày 15/8/2007 của Bộ trưởng Bộ Giáo dục và Đào tạo.

- "Quy chế đào tạo theo học chế tín chî" được ban hành theo Quyết định số 1368/QĐ/ĐHQG ĐH\&SĐH ngày 21/11/ 2008 của Giám đốc Đại học Quốc gia Thành phố Hồ Chí Minh.

- "Quy chế đào tạo theo hệ thống tín chỉ bậc đại học hệ chính quy" được ban hành theo Quyết định số 64/QĐ-ĐT ngày 16/02/2009 của Hiệu trưởng Trường Đại học Khoa học Xã hội và Nhân văn, Đại học Quốc gia TPHCM. 
- "Quy chế quản lý người nước ngoài học tập tại Việt Nam" của Bộ Giáo dục và Đào tạo ban hành kèm theo Thông tư số 03/2014/TT-BGDĐT ngày 25 tháng 02 năm 2014 của Bộ trưởng Bộ Giáo dục và Đào tạo.

\section{Khối lượng kiến thức toàn khoá}

Chương trình đào tạo cử nhân Việt Nam học cho sinh viên nước ngoài được thiết kế với khối lượng kiến thức tối thiểu cho toàn khoá học là 140 tín chỉ, gồm hai khối kiến thức: kiến thức giáo dục đại cương (45 tín chỉ) và kiến thức giáo dục chuyên nghiệp (95 tín chỉ).

Thực tập thực tế và khoá luận tốt nghiệp thuộc kiến thức giáo dục chuyên nghiệp: Thực tập - thực tế được tính bằng 04 tín chỉ; khoá luận tốt nghiệp được tính bằng 10 tín chỉ (dành cho sinh viên đủ điều kiện được chọn làm khoá luận tốt nghiệp).

Sinh viên nước ngoài được miễn 02 học phần Giáo dục thể chất và Giáo dục Quốc phòng.

\section{4. Đối tượng tuyển sinh}

Đối tượng tuyển sinh cho chương trình đào tạo cử nhân chuyên ngành Việt Nam học gồm những nhóm người sau:

a) Những người nước ngoài có nguyện vọng học bậc đại học chuyên ngành Việt Nam học.

b) Những người gốc Việt ở nước ngoài muốn tìm hiểu sâu về ngôn ngữ, văn hoá dân tộc.

Điều kiện dự tuyển: Những người muốn theo học chính thức chương trình hệ Cử nhân ngành Việt Nam học phải tốt nghiệp phổ thông trung học (hệ 12 năm) hoặc văn bằng tương đương và phải qua kỳ thi kiểm tra trình độ tiếng Việt (trình độ cơ sở).

Sinh viên chuyên ngành Việt Nam học của các trường đại học nước ngoài có thỏa thuận hợp tác với Trường Đại học Khoa học Xã hội và Nhân văn có thể được Trường Đại học Khoa học Xã hội và Nhân văn xem xét tiếp nhận học chuyển tiếp tại Khoa Việt Nam học.

\section{Quy trình đào tạo, điều kiện tốt nghiệp}

\subsection{Quy trình đào tạo:}

- Chương trình đào tạo bậc Cử nhân ngành Việt Nam học hệ chính quy được tổ chức theo học chế tín chỉ. Học chế này yêu cầu sinh viên phải tích lũy tối thiểu 140 tín chỉ gồm cả hai khối kiến thức đại cương và chuyên nghiệp trong khoảng thời gian từ 3,5 năm đến 6 năm học (tuỳ theo khả năng học tập của sinh viên).

- Để tiếp thu được một tiết học lý thuyết kéo dài 50 phút trên lớp, sinh viên phải cần từ 2 đến 3 tiết chuẩn bị, tự học, tự nghiên cứu ở nhà, một tiết học thực hành hoặc bài tập trên lớp cần từ 1 đến 2 tiết chuẩn bị ở nhà.

- Trong quá trình học tập và rèn luyện, sinh viên phải chấp hành đúng những nội quy, quy định của nhà trường; phải tham gia học tập, nghiên cứu, dự đầy đủ các buổi làm bài tập thực hành, thực tập, kiểm tra giữa kỳ, thi hết môn học để tích lũy đủ khối lượng kiến thức cần thiết.

- Cuối khoá học, những sinh viên hội đủ tất cả các điều kiện theo quy định của Nhà trường thì sẽ được xem xét công nhận và cấp bằng tốt nghiệp.

\section{2. Điều kiện tốt nghiệp:}

Sinh viên hội đủ những điều kiện sau đây thì được Hiệu trưởng Nhà trường xem xét cấp bằng Cử nhân ngành Việt Nam học:

- Sinh viên tích lũy đủ số lượng tín chỉ theo quy định trong chương trình đào tạo (tổng cộng tối thiểu 140 tín chỉ cho toàn khoá học).

- Không còn nợ Nhà trường bất cứ thứ gì, kể cả điểm các học phần, học phí, sách báo của Thư viện v.v...

\section{Thang điểm:}

Thang điểm được tính theo thang điểm 10. Điểm kiểm tra, điểm thi cuối môn học được tính theo thang điểm 10, làm tròn đến 0,5 . Điểm trung bình chung học kỳ và điểm trung bình chung tích lũy được lấy đến 02 chữ số thập phân.

\section{Nội dung chương trình}

* Chương trình đào tạo cử nhân Việt Nam học có tổng số tín chỉ tích luỹ toàn khoá là 140 tín chỉ, với khung kiến thức tổng quát như sau:

\begin{tabular}{|l|c|l|}
\hline \multicolumn{1}{|c|}{ Khối kiến thức } & Khối lượng tín chỉ & Ghi chú \\
\hline 1. Giáo dục đại cương & 35 tín chỉ. & \\
\hline 2. Giáo dục chuyên nghiệp & 105 tín chỉ & \\
\hline 2.1. Kiến thức cơ sở & 60 tín chỉ & \\
\hline 2.2. Kiến thức ngành & 45 tín chỉ & \\
\hline Tổng cộng & 140 tín chỉ & \\
\hline
\end{tabular}

* Nội dung chương trình đào tạo cử nhân Việt Nam học được thiết kế cụ thể như sau:

\begin{tabular}{|c|c|c|c|}
\hline TT & Mã & Tên môn học (Subject & Tín chỉ \\
\hline
\end{tabular}




\begin{tabular}{|c|c|c|c|c|c|}
\hline 2 & DAI020 & $\begin{array}{l}\text { Lôgich học đại cương } \\
\text { (Introduction to Logic) }\end{array}$ & 02 & 02 & \\
\hline 3 & DAI022 & $\begin{array}{l}\text { Tâm lý học đại cương } \\
\text { (Introduction } \\
\text { Psychology) }\end{array}$ & 02 & 02 & \\
\hline 4 & DAI023 & $\begin{array}{l}\text { Nhân học đại cương } \\
\text { (Introduction } \\
\text { Anthropology) }\end{array}$ & 02 & 02 & \\
\hline 5 & DAI024 & $\begin{array}{l}\text { Pháp luật đại cương } \\
\text { (Introduction to General } \\
\text { Law) }\end{array}$ & 02 & 02 & \\
\hline 6 & DAI026 & $\begin{array}{l}\text { Kinh tế học đại cương } \\
\text { (Overview of economics) }\end{array}$ & 02 & 02 & \\
\hline 7 & DAI028 & $\begin{array}{l}\text { Chính trị học đại cương } \\
\text { (Introduction to Politics) }\end{array}$ & 02 & 02 & \\
\hline 8 & DAI039 & $\begin{array}{l}\text { Tôn giáo học đại cương } \\
\text { (Introduction to Religious } \\
\text { Studies) }\end{array}$ & 02 & 02 & \\
\hline \multicolumn{3}{|c|}{$\begin{array}{l}\text { 7.1.3 Tin học đại cương (Overview of } \\
\text { Computing): Sinh viên tự tích luỹ và nộp } \\
\text { chứng chì }\end{array}$} & 03 & & \\
\hline \multicolumn{3}{|c|}{$\begin{array}{l}7.2 \text { Kiến thức giáo dục chuyên nghiệp } \\
\text { (Major Subjects/Professional Educational } \\
\text { Knowledge) }\end{array}$} & 105 & & \\
\hline \multicolumn{3}{|c|}{ 7.2.1 Kiến thức cơ sở (Common subjects) } & 60 & 24 & 36 \\
\hline 1 & VNH021 & $\begin{array}{l}\text { Tiếng Việt trung cấp: Đọc } \\
\text { (Intermediate Vietnamese: } \\
\text { Reading) }\end{array}$ & 05 & 02 & 03 \\
\hline 2 & VNH022 & $\begin{array}{l}\text { Tiếng Việt trung cấp: Nghe } \\
\text { (Intermediate Vietnamese: } \\
\text { Listening) }\end{array}$ & 05 & 02 & 03 \\
\hline 3 & VNH023 & $\begin{array}{l}\text { Tiếng Việt trung cấp: Nói } \\
\text { (Intermediate Vietnamese: } \\
\text { Speaking) }\end{array}$ & 05 & 02 & 03 \\
\hline 4 & VNH024 & $\begin{array}{l}\text { Tiếng Việt trung cấp: Viết } \\
\text { (Intermediate Vietnamese: } \\
\text { Writing) }\end{array}$ & 05 & 02 & 03 \\
\hline 5 & VNH030 & $\begin{array}{l}\text { Tiếng Việt nâng cao: Đọc } \\
\text { (Advanced Vietnamese: } \\
\text { Reading) }\end{array}$ & 05 & 02 & 03 \\
\hline 6 & VNH031 & $\begin{array}{l}\text { Tiếng Việt nâng cao: Nghe } \\
\text { (Advanced Vietnamese: } \\
\text { Listening) }\end{array}$ & 05 & 02 & 03 \\
\hline 7 & VNH032 & $\begin{array}{l}\text { Tiếng Việt nâng cao: Nói } \\
\text { (Advanced Vietnamese: } \\
\text { Speaking) }\end{array}$ & 05 & 02 & 03 \\
\hline 8 & VNH033 & $\begin{array}{l}\text { Tiếng Việt nâng cao: Viết } \\
\text { (Advanced Vietnamese: } \\
\text { Writing })\end{array}$ & 05 & 02 & 03 \\
\hline 9 & VNH025 & $\begin{array}{l}\text { Tiếng Việt học thuật: Đọc } \\
\text { (Academic Vietnamese: } \\
\text { Reading) }\end{array}$ & 05 & 02 & 03 \\
\hline
\end{tabular}




\begin{tabular}{|c|c|c|c|c|c|}
\hline 10 & VNH026 & $\begin{array}{l}\text { Tiếng Việt học thuật: Nghe } \\
\text { (Academic Vietnamese: } \\
\text { Listening) }\end{array}$ & 05 & 02 & 03 \\
\hline 11 & VNH027 & $\begin{array}{l}\text { Tiếng Việt học thuật: Nói } \\
\text { (Academic Vietnamese: } \\
\text { Speaking) }\end{array}$ & 05 & 02 & 03 \\
\hline 12 & VNH028 & $\begin{array}{l}\text { Tiếng Việt học thuật: Viết } \\
\text { (Academic Vietnamese: } \\
\text { Writing) }\end{array}$ & 05 & 02 & 03 \\
\hline $\begin{array}{l}7.2 .2 \\
\text { subj }\end{array}$ & $\begin{array}{l}\text { Kiến tr } \\
\text { cts) }\end{array}$ & hức ngành (Specialized & 45 & & \\
\hline $\begin{array}{l}7.2 .2 \\
\text { nhór } \\
\text { Subj }\end{array}$ & $\begin{array}{l}\text { 1. Kiến th } \\
\text { học phầ } \\
\text { ects) }\end{array}$ & $\begin{array}{l}\text { hức chung của ngành - } \\
\text { in bắt buộc (Compulsory }\end{array}$ & 25 & 24 & 02 \\
\hline 1 & VNH003 & $\begin{array}{l}\text { Các hệ ngôn ngữ ở Việt } \\
\text { Nam (Language Families in } \\
\text { Vietnam) }\end{array}$ & 02 & 02 & 00 \\
\hline 2 & VNH005 & $\begin{array}{l}\text { Các tôn giáo ở Việt Nam } \\
\text { (Religions in Vietnam) }\end{array}$ & 02 & 02 & 00 \\
\hline 3 & VNH006 & $\begin{array}{l}\text { Đại cương văn học Việt } \\
\text { Nam } \\
\text { (Introduction to Vietnamese } \\
\text { Literature) }\end{array}$ & 03 & 03 & 00 \\
\hline 4 & VNH009 & $\begin{array}{l}\text { Địa lý Việt Nam: tự nhiên, } \\
\text { nhân văn, kinh tế (Natural, } \\
\text { Human and Economic } \\
\text { Geography of Vietnam) }\end{array}$ & 02 & 02 & 00 \\
\hline 5 & VNH013 & $\begin{array}{l}\text { Ngữ pháp tiếng Việt } \\
\text { (Vietnamese Grammar) }\end{array}$ & 03 & 02 & 01 \\
\hline 6 & VNH015 & $\begin{array}{l}\text { Nhập môn khu vực học và } \\
\text { Việt Nam học (Introduction } \\
\text { to Area and Vietnamese } \\
\text { Studies) }\end{array}$ & 03 & 03 & 00 \\
\hline 7 & VNH036 & $\begin{array}{l}\text { Văn hoá du lịch Việt Nam } \\
\text { (Vietnam's Tourist Culture) }\end{array}$ & 02 & 01 & 01 \\
\hline 8 & VNH039 & $\begin{array}{l}\text { Văn hoá các dân tộc ở Việt } \\
\text { Nam (Ethnic groups' } \\
\text { cultures in Vietnam) }\end{array}$ & 02 & 02 & 00 \\
\hline 9 & VNH040 & $\begin{array}{l}\text { Kinh tế Việt Nam } \\
\text { (Vietnamese Economy) }\end{array}$ & 02 & 02 & 00 \\
\hline 10 & VNH041 & $\begin{array}{l}\text { Hệ thống chính trị Việt Nam } \\
\text { hiện đại (Modern Political } \\
\text { System of Vietnam) }\end{array}$ & 02 & 02 & 00 \\
\hline 11 & VNH046 & $\begin{array}{l}\text { Văn học dân gian Việt Nam } \\
\text { (Vietnamese } \\
\text { Literature) }\end{array}$ & 02 & 02 & 00 \\
\hline \multicolumn{3}{|c|}{$\begin{array}{l}\text { 7.2.2.2. Kiến thức chuyên sâu của ngành - } \\
\text { Nhóm học phần tụ̣ chọn (Optional } \\
\text { Subjects): Sinh viên chọn } 16 \text { tín chỉ trong } \\
\text { các học phần sau }\end{array}$} & 16 & & \\
\hline \multicolumn{3}{|c|}{$\begin{array}{l}\text { Nhóm các học phần về văn hoá, xã hội, } \\
\text { kinh tế } \\
\text { (Culture, Society, Economy Module) }\end{array}$} & 16 & 16 & 00 \\
\hline 1 & VNH001 & $\begin{array}{l}\text { ASEAN và Quan hệ VN - } \\
\text { ASEAN } \\
\text { (ASEAN and Relationship } \\
\text { between Vietnam and }\end{array}$ & 02 & 02 & 00 \\
\hline
\end{tabular}$$
\text { . }
$$

$$
\text { . }
$$$$
\text { . }
$$ 


\begin{tabular}{|c|c|c|c|c|c|}
\hline & & ASEAN) & & & \\
\hline 2 & VNH002 & 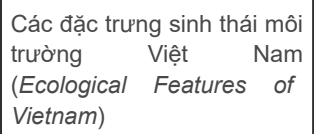 & 02 & 02 & 00 \\
\hline 3 & VNH008 & $\begin{array}{l}\text { Địa lý và cư dân các nước } \\
\text { Đông Nam Á (Geography } \\
\text { and Peoples in Southeast } \\
\text { Asia) }\end{array}$ & 02 & 02 & 00 \\
\hline 4 & VNH035 & $\begin{array}{l}\text { Văn hoá bảo đảm đời sống } \\
\text { ở Việt Nam (Life-sustaining } \\
\text { cultures in Vietnam) }\end{array}$ & 02 & 02 & 00 \\
\hline 5 & VNH037 & $\begin{array}{l}\text { Văn hoá ứng xử Việt Nam } \\
\text { (Etiquettes in Vietnamese } \\
\text { Culture) }\end{array}$ & 02 & 02 & 00 \\
\hline 6 & VNH038 & $\begin{array}{l}\text { Văn hoá Đông Nam Á } \\
\text { (Southeast Asian Culture) }\end{array}$ & 02 & 02 & 00 \\
\hline 7 & VNH039 & $\begin{array}{l}\text { Các dân tộc ở Việt Nam } \\
\text { (Ethnic groups in Vietnam) }\end{array}$ & 02 & 02 & 00 \\
\hline 8 & LSU065 & $\begin{array}{l}\text { Khảo cổ học Việt Nam } \\
\text { (Vietnamese Archeology) }\end{array}$ & 02 & 02 & 00 \\
\hline \multicolumn{3}{|c|}{$\begin{array}{l}\text { Nhóm các học phần về khoa học ngữ văn } \\
\text { (Philology Module) }\end{array}$} & 22 & 13 & 09 \\
\hline 1 & VNH004 & $\begin{array}{l}\text { Các phương tiện liên kết và } \\
\text { soạn thảo văn bản tiếng } \\
\text { Việt } \quad \text { (Vietnamese } \\
\text { Connectives and Writing) }\end{array}$ & 02 & 01 & 01 \\
\hline 2 & VNH011 & $\begin{array}{l}\text { Lý thuyết dịch } \\
\text { (Translation Theory) }\end{array}$ & 02 & 01 & 01 \\
\hline 3 & VNH012 & $\begin{array}{l}\text { Ngữ âm tiếng Việt thực } \\
\text { hành } \\
\text { (Vietnamese } \\
\begin{array}{l}\text { Phonetics) } \\
\text { Practical }\end{array}\end{array}$ & 02 & 01 & 01 \\
\hline 6 & VNH016 & $\begin{array}{l}\text { Phương ngữ tiếng Việt } \\
\text { (Vietnamese Dialects) }\end{array}$ & 02 & 02 & 00 \\
\hline 4 & VNH017 & $\begin{array}{l}\text { Phương pháp giảng dạy } \\
\text { ngoại ngữ } \\
\text { (Methods in Teaching } \\
\text { Foreign Languages) }\end{array}$ & 02 & 01 & 01 \\
\hline 5 & DAI014 & $\begin{array}{l}\text { Ngôn ngũ̃ học đối chiếu } \\
\text { (Contrastive Linguistics) }\end{array}$ & 02 & 02 & 00 \\
\hline 6 & VNH020 & $\begin{array}{l}\text { Tiếng Việt báo chí } \\
\text { (Media Vietnamese) }\end{array}$ & 02 & 01 & 01 \\
\hline 7 & VNH029 & $\begin{array}{l}\text { Tiếng Việt thương mại } \\
\text { (Business Vietnamese) }\end{array}$ & 02 & 01 & 01 \\
\hline 8 & VNH034 & $\begin{array}{ll}\text { Từ vựng tiếng } & \text { Việt thực } \\
\text { hành } & \\
\text { (Vietnamese } & \text { Practical } \\
\text { Lexicology) } & \end{array}$ & 02 & 01 & 01 \\
\hline 9 & VNH039 & $\begin{array}{l}\text { Lịch sử tiếng Việt } \\
\text { (History of Vietnamese } \\
\text { Language) }\end{array}$ & 02 & 02 & 00 \\
\hline 01 & VNH044 & $\begin{array}{l}\text { Phong cách học tiếng Việt } \\
\text { (Vietnamese Stylistics) }\end{array}$ & 02 & 01 & 01 \\
\hline
\end{tabular}




\begin{tabular}{|c|c|c|c|c|c|}
\hline 11 & VNH045 & $\begin{array}{l}\text { Từ Hán - Việt } \\
\text { (Sino-Vietnamese Lexicon) }\end{array}$ & 02 & 01 & 01 \\
\hline 12 & VNH047 & $\begin{array}{l}\text { Truyện ngắn Việt Nam hiện } \\
\text { đại } \\
\text { (Modern Vietnamese Short } \\
\text { Stories) }\end{array}$ & 02 & 02 & 00 \\
\hline \multicolumn{3}{|c|}{$\begin{array}{l}\text { 7.2.2.3 Thực tập thực tế (Internship/Field } \\
\text { trip) }\end{array}$} & 04 & & \\
\hline 1 & VNH019 & $\begin{array}{l}\text { Thực tập thực tế } \\
\text { (Internship/Field trip) }\end{array}$ & 04 & 00 & 04 \\
\hline \multicolumn{3}{|c|}{ 7.2.2.4 Khoá luận tốt nghiệp } & 10 & & \\
\hline 1 & VNH010 & $\begin{array}{l}\text { Khoá luận tốt nghiệp } \\
\text { (Thesis) } 5\end{array}$ & 10 & 00 & 10 \\
\hline $\begin{array}{l}\text { TỎ } \\
\text { (To }\end{array}$ & CỌNG & TíN CHİ CÀN TíCH LUỸ & 140 & & \\
\hline
\end{tabular}

\section{Dự kiến kế hoạch giảng dạy}

Theo học chế tín chỉ, để tạo điều kiện cho sinh viên được chủ động trong việc lập kế hoạch học tập của mình, trong mỗi năm học, toàn bộ các học phần bắt buộc sẽ được bố trí trong hai học kỳ chính của mỗi năm học. (Các học kỳ $1,3,5$ được tổ chức từ tháng 9 đến tháng 1 ; các học kỳ 2, 4, 6 được tổ chức từ tháng 2 đến tháng 6).

Học kỳ Hè sẽ được tổ chức cho những sinh viên thi không đạt một số học phần ở học kỳ chính được đăng ký học lại hoặc cho những sinh viên giỏi muốn học để kết thúc sớm chương trình đào tạo.

\begin{tabular}{|c|c|c|c|c|c|}
\hline \multirow{2}{*}{$\begin{array}{l}\text { Số } \\
\text { TT }\end{array}$} & \multirow{2}{*}{$\begin{array}{l}\text { Mã môn } \\
\text { học }\end{array}$} & \multirow[b]{2}{*}{ Tên môn học } & \multicolumn{3}{|c|}{ Số tín chỉ } \\
\hline & & & $\begin{array}{l}\text { Tổng } \\
\text { số }\end{array}$ & $\begin{array}{c}\text { Lý } \\
\text { thuyêt }\end{array}$ & $\begin{array}{l}\text { Thực } \\
\text { hành }\end{array}$ \\
\hline \multicolumn{3}{|c|}{ Học kỳ thứ 1: } & & & \\
\hline 1 & VNH021 & $\begin{array}{l}\text { Tiếng Việt trung cấp: Đọc } \\
\text { (Intermediate Vietnamese: } \\
\text { Reading) }\end{array}$ & 05 & 02 & 03 \\
\hline 2 & VNH022 & $\begin{array}{l}\text { Tiếng Việt trung cấp: Nghe } \\
\text { (Intermediate Vietnamese: } \\
\text { Listening) }\end{array}$ & 05 & 02 & 03 \\
\hline 3 & VNH023 & $\begin{array}{l}\text { Tiếng Việt trung cấp: Nói } \\
\text { (Intermediate Vietnamese: } \\
\text { Speaking) }\end{array}$ & 05 & 02 & 03 \\
\hline 4 & VNH024 & $\begin{array}{l}\text { Tiếng Việt trung cấp: Viết } \\
\text { (Intermediate Vietnamese: } \\
\text { Writing) }\end{array}$ & 05 & 02 & 03 \\
\hline & $\begin{array}{l}\text { Tổng } \\
\text { cộng }\end{array}$ & & 20 & 8 & 12 \\
\hline \multicolumn{5}{|c|}{$\begin{array}{l}\text { Học kỳ thứ 2: (Điều kiện: SV phải tích lũy được các học phần ở } \\
\text { học kỳ thứ 1) }\end{array}$} & \\
\hline 1 & VNH030 & $\begin{array}{l}\text { Tiếng Việt nâng cao: Đọc } \\
\text { (Advanced Vietnamese: Reading) }\end{array}$ & 05 & 02 & 03 \\
\hline 2 & VNH031 & $\begin{array}{l}\text { Tiếng Việt nâng cao: Nghe } \\
\text { (Advanced } \\
\text { Listening) }\end{array}$ & 05 & 02 & 03 \\
\hline 3 & VNH032 & $\begin{array}{l}\text { Tiếng Việt nâng cao: Nói } \\
\text { (Advanced Vietnamese: } \\
\text { Speaking) }\end{array}$ & 05 & 02 & 03 \\
\hline 4 & VNH033 & Tiếng Việt nâng cao: Viết & 05 & 02 & 03 \\
\hline
\end{tabular}




\begin{tabular}{|l|l|l|c|c|c|}
\hline \multirow{2}{*}{$\begin{array}{c}\text { Số } \\
\text { TT }\end{array}$} & \multirow{2}{*}{$\begin{array}{c}\text { Mã môn } \\
\text { học }\end{array}$} & \multicolumn{1}{|c|}{ Tên môn học } & \multicolumn{3}{|c|}{ Số tín chỉ } \\
\cline { 4 - 7 } & & $\begin{array}{c}\text { Tổng } \\
\text { số }\end{array}$ & $\begin{array}{c}\text { Lý } \\
\text { thuyết }\end{array}$ & $\begin{array}{c}\text { Thực } \\
\text { hành }\end{array}$ \\
\hline 5 & VNH018 & $\begin{array}{l}\text { Phương pháp học đại học } \\
\text { (Study Methods at University) }\end{array}$ & 02 & 02 & 00 \\
\hline & \multirow{2}{*}{ Tổng cộng } & & & \\
\hline
\end{tabular}

Học kỳ thứ 3 (Điều kiện: SV phải tích lũy được các học phần ở học kỳ thứ 2)

\begin{tabular}{|c|l|l|c|c|c|}
\hline 1 & VNH025 & $\begin{array}{l}\text { Tiếng Việt học thuật: Đọc } \\
\text { (Academic Vietnamese: Reading) }\end{array}$ & 05 & 02 & 03 \\
\hline 2 & VNH026 & $\begin{array}{l}\text { Tiếng Việt học thuật: Nghe } \\
\text { (Academic } \\
\text { Listening) }\end{array}$ & 05 & 02 & 03 \\
\hline 3 & VNH027 & $\begin{array}{l}\text { Tiếng Việt học thuật: Nói } \\
\text { (Academic } \\
\text { Speaking) }\end{array}$ & 05 & 02 & 03 \\
\hline 4 & VNH028 & $\begin{array}{l}\text { Tiếng Việt học thuật: Viết } \\
\text { (Academic Vietnamese: Writing) }\end{array}$ & 05 & 02 & 03 \\
\hline & Tổng cộng & $\mathbf{2 0}$ & $\mathbf{0 8}$ & 12 \\
\hline
\end{tabular}

Học kỳ thứ 4 (Điều kiện: SV phải tích lũy được các học phần ở học kỳ thứ 3)

\begin{tabular}{|c|l|l|l|l|c|}
\hline 1 & DAI001 & $\begin{array}{l}\text { Các nguyên lý cơ bản của Chủ } \\
\text { nghĩa Mác L Lênin phần I } \\
\text { (Marxism and Leninism Principles } \\
\text { I }\end{array}$ & 02 & 02 & 00 \\
\hline 2 & DAl002 & $\begin{array}{l}\text { Các nguyên lý cơ bản của Chủ } \\
\text { Cand }\end{array}$ & 03 & 03 & 00 \\
\hline
\end{tabular}




\begin{tabular}{|c|c|c|c|c|c|}
\hline \multirow{2}{*}{$\begin{array}{c}\text { Số } \\
\text { TT }\end{array}$} & $\begin{array}{c}\text { Mã môn } \\
\text { học }\end{array}$ & \multicolumn{1}{|c|}{ Tên môn học } & \multicolumn{3}{|c|}{ Số tín chỉ } \\
\cline { 3 - 6 } & & $\begin{array}{c}\text { Tổng } \\
\text { số }\end{array}$ & $\begin{array}{c}\text { Lý } \\
\text { thuyết }\end{array}$ & $\begin{array}{c}\text { Thực } \\
\text { hành }\end{array}$ \\
\hline 4 & & $\begin{array}{l}\text { Chứng chỉ tin học (SV nộp chứng } \\
\text { chîn }\end{array}$ & 03 & 01 & 02 \\
\hline & Tổng cộng & 13 & 10 & 03 \\
\hline
\end{tabular}

Tổng cộng toàn khoá học sinh viên phải tích lũy tối thiểu 140 tín chỉ.

9. Mô tả vắn tắt nội dung và khối lượng các học phần

9.1 Các học phần thuộc khối kiến thức giáo dục đại cương

\subsubsection{Các học phần bắt buộc}

(1) Các nguyên lý cơ bản của Chủ nghĩa Mác - Lênin (5 tín chỉ)

Điều kiện tiên quyết: Sinh viên đã tích luỹ các học phần: Tiếng Việt trung cấp, nâng cao, và học các học phần Tiếng Việt học thuật.

Nội dung của học phần này đề cương môn học ban hành kèm theo Quyết định số 52/2008/QĐ-BGD\&ĐT ngày 18 tháng 09 năm 2008 của Bộ trưởng Bộ Giáo dục và Đào tạo.

\section{(2) Đường lối cách mạng của Đảng Cộng sản Việt Nam (3 tín chỉ)}

Điều kiện tiên quyết: Sinh viên đã tích luỹ các học phần: Tiếng Việt trung cấp, nâng cao, và học các học phần Tiếng Việt học thuật, tích luỹ các học phần Các nguyên lý cơ bản của chủ nghĩa Mác-Lênin.

Nội dung của học phần này đề cương môn học ban hành kèm theo Quyết định số 52/2008/QĐ-BGD\&ĐT ngày 18 tháng 09 năm 2008 của Bộ trưởng Bộ Giáo dục và Đào tạo.

(3) Tư tưởng Hồ Chí Minh (2 tín chỉ)

Điều kiện tiên quyết: Sinh viên đã tích luỹ các học phần: Tiếng Việt trung cấp, nâng cao, và học các học phần Tiếng Việt học thuật, các học phần Các nguyên lý cơ bản của chủ nghĩa Mác-Lênin.

Nội dung của học phần này đề cương môn học ban hành kèm theo Quyết định số 52/2008/QĐ-BGD\&ĐT ngày 18 tháng 09 năm 2008 của Bộ trưởng Bộ Giáo dục và Đào tạo.

\section{(4) Phương pháp học đại học (2 tín chỉ)}

Môn học này cung cấp cho sinh viên những hiểu biết căn bản cần thiết về các phương pháp học ở Đại học.

Sinh viên được cung cấp những kỹ năng cần thiết cho việc học ở trường đại học như tính tự chủ trong học tập, cách quản lý thời gian, phương pháp tra tìm thông tin, kỹ năng nghe giảng và ghi chép trong lớp, kỹ năng đọc, thảo luận và thuyết trình trong lớp, kỹ năng làm việc theo nhóm, kỹ năng chuẩn bị cho kỳ thi, giải toả căng thẳng nhằm giúp cho sinh viên thích nghi tốt hơn với môi trường học tập ở bậc đại học

\section{(5) Tin học đại cương (3 tín chỉ)}

\section{Điều kiện tiên quyết: không}

Môn học trang bị cho sinh viên các khái niệm cơ bản về xử lý thông tin và máy tính điện tử; đồng thời cũng giúp sinh viên nắm vững các thao tác truy cập Internet, các kỹ năng sử dụng hệ điều hành để thao tác trên máy tính điện tử, khai thác một số phần mềm ứng dụng, soạn thảo và lưu trữ các văn bản phục vụ công tác văn phòng, sử dụng hệ quản trị cơ sở dữ liệu để tính toán khoa học và giải quyết các vấn đề chuyên môn (chứng chỉ $\mathrm{A}$ hoặc chứng chỉ tin học văn phòng).

\section{(6) Thống kê cho khoa học xã hội (2 tín chỉ)}

Điều kiện tiên quyết: Sinh viên đã tích luỹ các học phần: Tiếng Việt trung cấp, nâng cao, và học các học phần Tiếng Việt học thuật.

Môn học cung cấp cho sinh viên những khái niệm và kiến thức cơ bản về thống kê, cụ thể là về điều tra thống kê, về độ tin cậy của một cuộc điều tra thống kê, về cách so sánh độ tương hợp của các kết quả thống kê, về sự tương quan giữa những yếu tố cùng ảnh hưởng tới cùng một sự kiện, về cách kiểm tra những giả thuyết thống kê trong nghiên cứu khoa học...

\section{(7) Môi trường và phát triển (2 tín chỉ)}

Điều kiện tiên quyết: Sinh viên đã tích luỹ các học phần: Tiếng Việt trung cấp, nâng cao, và học các học phần Tiếng Việt học thuật.

Môn học cung cấp cho sinh viên các khái niệm và nội dung cơ bản về môi trường toàn cầu và Việt Nam; mối quan hệ biện chứng giữa môi trường và phát triển hiện nay - phát triển bền vững và phát triển không bền vững (tại các kiểu vùng sinh thái cơ bản: nông thôn và đô thị ở Việt nam); về vai trò của nhà nước, các tổ chức phi chính phủ và cộng đồng trong bảo vệ môi trường và phát triển bền vững.

Môn học cũng trang bị cho sinh viên một số phương pháp ưu thế trong đánh giá phát triển; tạo lập các phương pháp tư 
duy hệ thống trong nhận thức các vấn đề về môi trường và pháp triển.

\section{(8) Cơ sở văn hoá Việt Nam (2 tín chỉ)}

Điều kiện tiên quyết: Sinh viên đã tích luỹ các học phần: Tiếng Việt trung cấp, nâng cao, và học các học phần Tiếng Việt học thuật.

Môn học cung cấp những khái niệm chung về văn hoá học và văn hoá Việt Nam, về hệ thống các thành tố văn hoá Việt Nam và những đặc trưng của chúng.

Môn học cũng trang bị những kỹ năng, phương pháp tiếp cận tìm hiểu và nghiên cứu những vấn đề của văn hoá Việt Nam.

\section{(9) Lịch sử văn minh thế giới (3 tín chỉ)}

Điều kiện tiên quyết: Sinh viên đã tích luỹ các học phần: Tiếng Việt trung cấp, nâng cao, và học các học phần Tiếng Việt học thuật.

Môn học cung cấp cho sinh viên những kiến thức cơ bản và hệ thống về sự phát triển văn minh nhân loại (qua những nền văn minh tiêu biểu ở Ai Cập, Lưỡng Hà, Án Độ, Trung Hoa, Hy-La...), về bước chuyển sang nền văn minh công nghiệp và văn minh thông tin; những nguyên tắc và mối tương quan giữa hội nhập văn minh thế giới và giữ vững và phát huy bản sắc văn hoá dân tộc.

\section{(10) Tiến trình lịch sử Việt Nam (3 tín chỉ)}

Điều kiện tiên quyết: Sinh viên đã tích luỹ các học phần: Tiếng Việt trung cấp, nâng cao, và học các học phần Tiếng Việt học thuật.

Môn học cung cấp những kiến thức tổng quát về quá trình phát triển liên tục với những đặc điểm chủ yếu, những quy luật chung nhất của lịch sử Việt Nam, trong đó, nắm được đặc điểm nổi bật và xuyên suốt tiến trình lịch sử Việt Nam là công cuộc giữ nước chống ngoại xâm luôn xong hành cùng công cuộc xây dựng và phát triển của đất nước.

Ngoài việc nắm vững những chặng đường lịch sử dựng nước và giữ nước của dân tộc Việt Nam, sinh viên còn được trang bị kiến thức về lịch sử Việt Nam với tư cách là lịch sử của các cộng đồng quốc gia, dân tộc đã và đang sống trên lãnh thổ Việt Nam hiện nay, cùng góp phần sáng tạo và bảo tồn nền văn hoá Việt Nam.

(11) Xã hội học đại cương (2 tín chỉ)

Điều kiện tiên quyết: Sinh viên đã tích luỹ các học phần: Tiếng Việt trung cấp, nâng cao, và học các học phần Tiếng Việt học thuật.

Môn học cung cấp cho người học những kiến thức cơ bản về xã hội học bao gồm quá trình hình thành và phát triển cũng như đối tượng nghiên cứu xã hội học, những khái niệm cơ bản và một số trường phái xã hội học, những thiết chế và tổ chức xã hội cơ bản.

Môn học cũng trang bị cho sinh viên kỹ năng thực hành, sử dụng các phương pháp định tính, định lượng trong nghiên cứu xã hội học.

\section{(12) Phương pháp nghiên cứu khoa học (2 tín chỉ)}

Điều kiện tiên quyết: Sinh viên đã tích luỹ các học phần: Tiếng Việt trung cấp, nâng cao, và học các học phần Tiếng Việt học thuật.

Môn học cung cấp cho sinh viên những kiến thức cơ bản về khoa học và nghiên cứu khoa học, về bản chất của nghiên cứu khoa học cũng như cấu trúc lôgic của một công trình khoa học.

Môn học cũng giúp sinh viên nắm vững được các thao tác nghiên cứu khoa học. biết xây dựng, chứng minh và trình bày các luận điểm khoa học. Qua đó, sinh viên có thể nắm được phương pháp trình bày một báo cáo khoa học, viết được một số công trình khoa học và bước đầu biết vận dụng kỹ năng nghiên cứu khoa học vào việc học tập ở đại học.

\section{(13) Dẫn luận Ngôn ngữ học (2 tín chỉ)}

Điều kiện tiên quyết: Sinh viên đã tích luỹ các học phần: Tiếng Việt trung cấp, nâng cao, và học các học phần Tiếng Việt học thuật.

Môn học cung cấp cho sinh viên những kiến thức cơ sở, cơ bản về ngôn ngữ học, từ đó tạo điều kiện cho sinh viên có thể hiểu sâu hơn về ngoại ngữ mà họ đang học.

Về nhận thức sinh viên được cung cấp kiến thức tổng luận về ngôn ngữ học (như bản chất, chức năng, nguồn gốc, sự phát triển của ngôn ngữ, hệ thống tín hiệu ngôn ngữ, v.v.) và kiến thức về các phân ngành của ngôn ngữ học (ngữ âm học, từ vựng - ngữ nghĩa học, ngữ pháp học, v.v.)

Về kỹ năng, học phần giúp sinh viên nâng cao các thao tác thực hành ngoại ngữ như phát âm chuẩn các âm tố, phân biệt âm vị và các biến thể; phân biệt được đa nghĩa và đồng âm, xác định cơ cấu nghĩa của từ; phân loại câu, viết câu đúng ngữ pháp..

\subsection{Các học phần tự chọn}

\section{(14) Tôn giáo học đại cương (2 tín chỉ)}

Điều kiện tiên quyết: Sinh viên đã tích luỹ các học phần: Tiếng Việt trung cấp, nâng cao, và học các học phần Tiếng Việt học thuật. Các sinh viên cũng phải tích luỹ các học phần Các nguyên lý cơ bản của chủ nghĩa Mác-Lênin.

Môn học cung cấp những kiến thức cơ bản về tôn giáo như nguồn gốc, các học thuyết và sinh hoạt tôn giáo; các tôn giáo lớn trên thế giới như Phật giáo, Cơ đốc giáo, Khổng giáo, Ân Độ giáo, Hồi giáo,...

\section{(15) Lôgich học đại cương (2 tín chỉ)}

Điều kiện tiên quyết: Sinh viên phải đã luỹ các học phần: Tiếng Việt trung cấp, nâng cao, và học các học phần Tiếng 
Việt học thuật.

Môn học nâng cao khả năng tư duy logic của sinh viên, giúp sinh viên nắm các quy luật/quy tắc logic trong suy nghĩ, tranh luận, trình bày; phân biệt phân biệt đúng - sai trong suy luận; tránh nguỵ biện; biết chứng minh, bác bỏ một quan điểm, luận điểm.

\section{(16) Tâm lý học đại cương (2 tín chỉ)}

Điều kiện tiên quyết: Sinh viên đã tích luỹ các học phần: Tiếng Việt trung cấp, nâng cao, và học các học phần Tiếng Việt học thuật.

Môn học cung cấp những kiến thức liên quan đến tâm lý con người như bản chất, nguồn gốc, những quy luật cơ bản của quá trình hình thành, vận hành và phát triển của các hiện tượng tâm lý.

\section{(17) Nhân học đại cương (2 tín chỉ)}

Điều kiện tiên quyết: đã tích luỹ các học phần: Tiếng Việt trung cấp, nâng cao, và học các học phần Tiếng Việt học thuật.

Môn học cung cấp cho sinh viên những kiến thức về sự tiến hoá của con người về mặt sinh học và văn hoá; về tộc người và quá trình tộc người; các kiến thức về văn hoá, tôn giáo, kinh tế, gia đình, phân tần xã hội,...

\section{(18) Pháp luật đại cương (2 tín chỉ)}

Điều kiện tiên quyết: Sinh viên đã tích luỹ các học phần: Tiếng Việt trung cấp, nâng cao, và học các học phần Tiếng Việt học thuật.

Môn học giới thiệu những kiến thức cơ bản về nhà nước và pháp luật.

Phần nhà nước gồm khái niệm, bản chất của nhà nước, các hình thức nhà nước trên thế giới.

Phần pháp luật gồm khái niệm, bản chất của pháp luật, quan hệ pháp luật, trách nhiệm pháp lý, các chế định cơ bản của một số ngành luật trong hệ thống Pháp luật Việt Nam.

\section{(19) Kinh tế học đại cương (2 tín chỉ)}

Điều kiện tiên quyết: Sinh viên đã tích luỹ các học phần: Tiếng Việt trung cấp, nâng cao, và học các học phần Tiếng Việt học thuật. Các sinh viên cũng phải tích luỹ các học phần Các nguyên lý cơ bản của chủ nghĩa Mác-Lênin.

Môn học trang bị cho sinh viên các khái niệm cơ bản và các nguyên lý chung của kinh tế vĩ mô và vi mô như các nguyên lý vận hành của nền kinh tế ở mức độ vĩ mô thông qua phân tích một số mô hình kinh tế vĩ mô cơ bản, phân tích chính sách kinh tế vĩ mô trong dài hạn, phân tích và giải thích diễn biến giá thị trường của các loại hàng hoá, hiểu và biết cách phân tích các chính sách can thiệp vào thị trường của chính phủ; nắm các khái niệm như cầu, cung, giá thị trường, độ co giãn..., các nguyên tắc lựa chọn hợp lý của người tiêu dùng và người sản xuất.

\section{(20) Chính trị học đại cương (2 tín chỉ)}

Điều kiện tiên quyết: Sinh viên đã tích luỹ các học phần: Tiếng Việt trung cấp, nâng cao, và học các học phần Tiếng Việt học thuật. Các sinh viên cũng phải tích luỹ các học phần Các nguyên lý cơ bản của chủ nghĩa Mác-Lênin.

Môn học trình bày những kiến thức cơ bản về chính trị học như khái niệm, lược sử khoa học chính trị trên thế giới; tình hình chính trị thế giới; quyền lực chính trị, lợi ích chính trị, quyết sách chính trị, xử lý các tình huống chính trị; một số mô hình chính trị của Tây Âu, Mỹ và khối ASEAN.

\subsection{Các học phần thuộc khối kiến thức giáo dục chuyên nghiệp}

\subsubsection{Các học phần thuộc khối kiến thức cơ sở}

\section{(21) Tiếng Việt trung cấp: Đọc (5 tín chỉ)}

Điều kiện tiên quyết: Sinh viên phải có những kiến thức cơ bản về tiếng Việt ở trình độ trung cấp 1 (Intermediate-Low), có khả năng đọc hiểu về các chủ đề thông thường.

Môn học này nhằm cung cấp và rèn luyện những kỹ thuật liên quan đến quá trình đọc hiểu, qua đó giúp sinh viên đọc hiểu những văn bản tương đối đơn giản về các chủ đề trong cuộc sống.

\section{(22) Tiếng Việt trung cấp: Nghe (5 tín chỉ)}

Điều kiện tiên quyết: Sinh viên phải có những kiến thức cơ bản về tiếng Việt ở trình độ trung cấp 1 (Intermediate-Low), có khả năng nghe hiểu về các chủ đề thông thường ở tốc độ nói chậm hoặc trung bình (chứng chỉ $\mathrm{A}$ Tiếng Việt do Trường ĐHKHXH\&NV cấp).

Môn học cung cấp cho sinh viên các kỹ năng nghe hiểu ở trình độ trung cấp 2 (Mid-Intermediate). Đặc biệt tập trung vào một số kỹ năng nghe như nghe ý chính, nghe chi tiết, nghe và sắp xếp thông tin, nghe và ghi chú thông tin, nghe số liệu, nghe kết hợp với nói và viết, v.v.

\section{(23) Tiếng Việt trung cấp: Nói (5 tín chỉ)}

Điều kiện tiên quyết: Sinh viên phải có những kiến thức cơ bản về tiếng Việt ở trình độ trung cấp 1 (Intermediate-Low), có khả năng giao tiếp về các chủ đề thông thường ở tốc độ nói chậm hoặc trung bình.

Môn học này nhằm rèn luyện các kỹ năng giao tiếp thông thường đồng thời chỉnh sửa các lỗi phát âm phổ biến ở sinh viên nước ngoài. Trong học phần này, sinh viên được hướng dẫn kỹ thuật giao tiếp với các chủ đề thông thường trong cuộc sống hàng ngày, cũng như bước đầu làm quen với kỹ thuật thuyết trình trước đám đông.

\section{(24) Tiếng Việt trung cấp: Viết (5 tín chỉ)}

Điều kiện tiên quyết: Sinh viên phải có những kiến thức cơ bản về tiếng Việt ở trình độ trung cấp 1 (Intermediate-Low). 
Môn học này nhằm rèn luyện cho sinh viên viết đúng chính tả và giúp sinh viên viết được các đoạn văn, các tin nhắn và các đoạn văn/bài viết ngắn về các chủ đề thông thường.

\section{(25) Tiếng Việt nâng cao: Đọc (5 tín chỉ)}

Điều kiện tiên quyết: Sinh viên đã tích lũy được học phần Tiếng Việt trung cấp - Đọc.

Học phần này nhằm cung cấp và rèn luyện những kỹ thuật liên quan đến quá trình đọc hiểu ở trình độ Trung cấp, giới thiệu cách tiếp cận với văn bản ở các thể loại khác nhau ở mức độ tương đối khó.

\section{(26) Tiếng Việt nâng cao: Nghe (5 tín chỉ)}

Điều kiện tiên quyết: Sinh viên đã tích lũy được học phần Tiếng Việt trung cấp - Nghe.

Nội dung học phần bao gồm những kỹ thuật nghe hiểu bậc nâng cao (Advanced Vietnamese) như nghe ý chính, nghe hiểu các sắc thái ngôn ngữ khác nhau, và các thao tác phân tích, tổng hợp nhằm nghe hiểu nội dung văn bản bao gồm các cuộc thoại có chủ đề liên quan đến cuộc sống hàng ngày, các cuộc thoại có tính chuyên môn.

\section{(27) Tiếng Việt nâng cao: Nói (5 tín chỉ)}

Điều kiện tiên quyết: Sinh viên đã tích lũy được học phần Tiếng Việt trung cấp - Nói.

Môn học này nhằm luyện cho sinh viên các kỹ năng giao tiếp nâng cao trong các cuộc thoại có chủ đề liên quan đến đời sống cá nhân, đời sống xã hội. Sinh viên học cách trình bày ý kiến về một vấn đề nào đó. Ngoài ra, kỹ thuật thuyết trình về một đề tài có tính chuyên môn cũng được dạy trong học phần này.

\section{(28) Tiếng Việt nâng cao: Viết (5 tín chỉ)}

Điều kiện tiên quyết: Sinh viên đã tích lũy được học phần Tiếng Việt trung cấp - Viết.

Học phần này nhằm rèn luyện cho sinh viên viết được các các bài viết ở các thể loại văn bản khác nhau như thư tín, tường thuật; bài viết có sử dụng những cấu trúc câu tương đối phức tạp; phân biệt được sự khác nhau giữa ngôn ngữ nói và ngôn ngữ viết.

\section{(29) Tiếng Việt học thuật: Đọc (5 tín chỉ)}

Điều kiện tiên quyết: Sinh viên đã tích lũy được học phần Tiếng Việt nâng cao - Đọc.

Học phần này giúp sinh viên nâng cao kỹ năng đọc hiểu văn bản tiếng Việt ở các thể loại, phong cách khác nhau: các bài đọc về môi trường, kỹ thuật, tự nhiên (phong cách báo chí), về khoa học xã hội (phong cách khoa học).Ngoài ra, ở mỗi đơn vị bài giảng còn có những bài đọc thêm tương tự để sinh viên thực hành. Sau mỗi bài, sinh viên phải tự tìm những văn bản có đề tài hoặc chủ đề tương tự và trao đổi theo nhóm.

\section{(30) Tiếng Việt học thuật: Nghe (5 tín chỉ)}

Điều kiện tiên quyết: Sinh viên đã tích lũy được học phần Tiếng Việt nâng cao -Nghe.

Nội dung của học phần này là cung cấp những kỹ thuật nghe hiểu nâng cao thông qua những văn bản được nói với nhiều tốc độ, phong cách, cũng như những chất giọng khác nhau của người Việt, nhằm chuẩn bị cho sinh viên khả năng nắm bắt khi tham dự các chuyên đề có tính chuyên ngành.

\section{(31) Tiếng Việt học thuật: Nói (5 tín chỉ)}

Điều kiện tiên quyết: Sinh viên đã tích lũy được học phần Tiếng Việt nâng cao - Nói

Học phần này giúp sinh viên luyện các kỹ năng giao tiếp nâng cao trong các cuộc thoại có chủ đề liên quan đến đờ' sống cá nhân, đời sống xã hội với mức độ phức tạp hơn, đặc biệt là thực tập những cách nói có tính ước lệ văn hoá của người Việt. Sinh viên học cách trình bày ý kiến hoặc thuyết trình về một vấn đề chuyên môn nào đó.

\section{(32) Tiếng Việt học thuật: Viết (5 tín chỉ)}

Điều kiện tiên quyết: Sinh viên đã tích lũy được học phần Tiếng Việt nâng cao - Viết.

Học phần này giúp sinh viên nâng cao kỹ năng viết, rèn luyện cách viết theo các phong cách khoa học, chính luận hành chính. Sinh viên thực hành sử dụng các phương tiện liên kết văn bản, xây dựng đề cương chi tiết và viết một văn bản hoàn chỉnh về một đề tài cho trước.

\subsubsection{Các học phần thuộc khối kiến thức ngành}

\subsubsection{Các học phần bắt buộc}

\section{(33) Các hệ ngôn ngữ ở Việt Nam (2 tín chỉ)}

Điều kiện tiên quyết: Sinh viên đã tích luỹ các học phần: Tiếng Việt trung cấp, nâng cao và học Tiếng Việt học thuật. Sinh viên cũng phải tích lũy học phần Dẫn luận Ngôn ngữ học.

Môn học cung cấp cho người học một cái nhìn toàn cảnh về các ngôn ngữ dân tộc ở Việt Nam, chỉ ra những mối quan hệ về nguồn gốc, quan hệ tiếp xúc, xu hướng phát triển chung của các ngôn ngữ dân tộc; phân loại ngôn ngữ theo nguồn gốc và loại hình; một số đặc điểm cơ bản (về ngữ âm, từ vựng, ngữ pháp) của các ngôn ngữ dân tộc; chính sách ngôn ngữ ở Việt Nam.

\section{(34) Các tôn giáo ở Việt Nam (2 tín chỉ)}

Điều kiện tiên quyết: Sinh viên đã học qua các học phần: Tiếng Việt trung cấp, Tiếng Việt nâng cao, Tiếng Việt học thuật và học phần Các nguyên lý cơ bản của Chủ nghĩa Mác - Lênin, Tôn giáo học đại cương.

Môn học cung cấp những kiến thức cơ bản về tín ngưỡng, tôn giáo; các tôn giáo bản địa; các nghi lễ, lễ hội mang màu sắc tín ngưỡng, tôn giáo tại Việt Nam.

(35) Đại cương văn học Việt Nam (3 tín chỉ) 
Điều kiện tiên quyết: Sinh viên đã tích luỹ các học phần: Tiếng Việt trung cấp, nâng cao, học thuật.

Học phần này cung cấp cho sinh viên một số kiến thức cơ bản và hệ thống về tiến trình lịch sử văn học Việt Nam, giúp sinh viên có cái nhìn tổng quát vể nền văn học Việt Nam. Môn học gồm những nội dung chủ yếu: nguồn gốc - đặc điểm của lịch sử văn học Việt Nam, sự phát triển của ngôn ngữ văn học Việt Nam về tiếng nói và chữ viết; văn học dân gian và các truyền thuyết về các cá nhân và tập thể anh hung, văn học thời dựng nước và giữ nước, văn học viết từ buổi đầu hình thành đến thế kỷ XV; văn học Việt Nam từ thời Pháp thuộc đến khi giành được độc lập, văn học từ sau khi giành được độc lập đến năm 1975, từ 1975 đến nay..

Học phần cũng luyện cho sinh viên khả năng đọc hiểu được tác giả, ngôn ngữ nghệ thuật tiếng Việt qua các tác phẩm tiêu biểu.

\section{(36) Địa lý Việt Nam: tự nhiên, nhân văn, kinh tế (2 tín chỉ)}

Điều kiện tiên quyết: Sinh viên đã tích luỹ các học phần: Tiếng Việt trung cấp, nâng cao, học các học phần Tiếng Việt học thuật.

Môn học giới thiệu bức tranh chung về địa lý Việt Nam, bao gồm cả tự nhiên và kinh tế - xã hội. Trên cơ sở nắm vững các đặc điểm cơ bản của thiên nhiên Việt Nam, sự phân bố các nguồn tài nguyên, đặc điểm dân cư và nguồn lao động của Việt Nam cũng như đặc điểm và sự phân bố của nền sản xuất xã hội, sinh viên có thể nhận thức sâu hơn về các nguồn lực phát triển kinh tế - xã hội của Việt Nam. Qua đó, sinh viên biết cách vận dụng những kiến thức đã thu nhận được vào việc giải quyết các vấn kinh tế - xã hội ở Việt Nam.

\section{(37) Ngữ pháp tiếng Việt (3 tín chỉ)}

Điều kiện tiên quyết: Sinh viên đã tích luỹ các học phần: Tiếng Việt trung cấp, nâng cao, Dẫn luận Ngôn ngữ học, .học các học phần Tiếng Việt học thuật.

Học phần này giới thiệu một cách hệ thống và đơn giản ngữ pháp tiếng Việt xét trên bình diện từ loại, ngữ đoạn, tình thái. Xuất phát từ ngữ đoạn - đơn vị trực tiếp tham gia cấu tạo câu - sinh viên sẽ tìm hiểu các loại ngữ đoạn khác nhau trên cơ sở phân biệt thuộc tính ngữ pháp của yếu tố trung tâm, tức phân biệt về mặt từ loại. Và sau đó, sinh viên sẽ tìm hiểu hoạt động của các ngữ đoạn trong câu, tức là khi nó đảm đương một chức vụ ngữ pháp trong câu. Sinh viên nắm được ý nghĩa của tình thái câu, những yếu tố tình thái làm thành đề của câu, những yếu tố tình thái được xử lý như phần thuyết của câu và những yếu tố tình thái khác của câu.

\section{(38) Nhập môn Khu vực học và Việt Nam học (3 tín chỉ)}

Điều kiện tiên quyết: Sinh viên đã luỹ các học phần: Tiếng Việt trung cấp, nâng cao, học học phần Tiếng Việt học thuật.

Môn học cung cấp những kiến thức nhập môn về lý thuyết khu vực học hiện đang được áp dụng rộng rãi trong các lĩnh vực khoa học xã hội và nhân văn: lịch sử hình thành và phát triển của khu vực học với tư cách một khoa học liên ngành; những khái niệm cơ bản; vai trò của khu vực học trong xu thế phát triển của khoa học hiện nay; đối tượng của khu vực học trong xu thế phát triển của khoa học hiện nay; giới hạn phạm vi nghiên cứu.

Môn học cũng trang bị những phương pháp tiếp cận và những thao tác của nghiên cứu khu vực để ứng dụng vào thực tiễn phục vụ các chương trình phát triển cũng như tổ chức các đề tài và chương trình nghiên cứu liên ngành.

\section{(39) Văn hoá du lịch Việt Nam (2 tín chỉ)}

Điều kiện tiên quyết: Sinh viên đã tích luỹ các học phần: Tiếng Việt trung cấp, nâng cao, và Cơ sở văn hoá Việt Nam học học phần Tiếng Việt học thuật.

Môn học cung cấp định nghĩa về du lịch, lịch sử và quá trình phát triển của du lịch, và các loại hình du lịch, khái niệm du lịch văn hoá và văn hoá du lịch; các yếu tố thu hút khách du lịch; các lý thuyết chính trong nghiên cứu văn hoá du lịch như Lý thuyết về việc xây dựng và sử dụng hình ảnh trong du lịch: (site = sight) hay là Lý thuyết về sự trưng bày văn hoá (cultural representation), Lý thuyết về sự chân thật (authenticity), Lý thuyết về quan hệ chủ-khách; khái niệm du lịch bền vững, các chỉ số phân tích về độ bền vững trong phát triển du lịch, vấn đề quản lí vi mô và vĩ mô theo định hướng phát triển du lịch bền vững, hướng đến một nền du lịch Việt Nam bền vững và phát triển.

\section{(40) Văn hoá các dân tộc ở Việt Nam (2 tín chỉ)}

Điều kiện tiên quyết: Sinh viên đã tích luỹ các học phần: Tiếng Việt trung cấp, nâng cao, và Cơ sở văn hoá Việt Nam; học các học phần Tiếng Việt học thuật.

Môn học cung cấp những đặc trưng của các dân tộc ít người tại Việt Nam ở các bình diện: văn hoá vật chất và phi vật chất theo nhóm/vùng văn hoá.

\section{(41) Kinh tế Việt Nam (2 tín chỉ)}

Điều kiện tiên quyết: Sinh viên đã tích luỹ các học phần: Tiếng Việt trung cấp, nâng cao. Các sinh viên cũng phải tích luỹ các học phần Các nguyên lý cơ bản của chủ nghĩa Mác - Lênin.

Môn học cung cấp cho sinh viên những kiến thức cơ bản về tiến trình phát triển lịch sử của kinh tế Việt Nam; đặc điểm các nguồn lực cho phát triển kinh tế Việt Nam; đặc điểm và xu thế phát triển của các thành phần kinh tế trong nền kinh tế thị trường theo định hướng Xã hội chủ nghĩa ở Việt Nam; sự phát triển và chuyển dịch cơ cấu nền kinh tế Việt Nam theo hướng công nghiệp hoá- hiện đại hoá và hội nhập quốc tế; triển vọng và định hướng chiến lược phát triển kinh tế Việt Nam trong giai đoạn hiện nay.

\section{(42) Hệ thống chính trị Việt Nam hiện đại (2 tín chỉ)}

Điều kiện tiên quyết: Sinh viên đã tích luỹ các học phần: Tiếng Việt trung cấp, nâng cao, Tiếng Việt học thuật. Các sinh viên cũng phải tích lũy học phần Tiến trình lịch sử Việt Nam, các học phần Những nguyên lý cớ bản của chủ nghĩa Mác - Lênin.

Môn học cung cấp các kiến thức chung về lịch sử hình thành và phát triển của hệ thống chính trị Việt Nam từ khi thành lập Nhà nước cách mạng sau tháng Tám 1945 đến nay: cơ cấu hệ thống, đặc điểm loại hình, quá trình phát triển. Đặc 
biệt học phần tập trung giới thiệu tính quy luật của sự ra đời và phát triển của hệ thống chính trị cách mạng và vai trò lãnh đạo tất yếu trong hệ thống chính trị của Đảng Cộng sản Việt Nam hiện nay, đồng thời chỉ ra những đòi hỏi khách quan của công cuộc cải cách hành chính trước yêu cầu mới của sự nghiệp công nghiệp hoá và hiện đại hoá.

\section{(43) Văn học dân gian Việt Nam (2 tín chỉ)}

Điều kiện tiên quyết: Sinh viên đã tích luỹ các học phần: Tiếng Việt trung cấp, nâng cao. Sinh viên cũng phải tích lũy học phần Đại cương văn học Việt Nam.

Cung cấp những kiến thức về diện mạo của văn học dân gian Việt Nam nói chung: những đặc điểm cơ bản của văn học dân gian; quá trình phát triển của văn học dân gian Việt Nam; các hình thức, đặc trưng của từng thể loại của văn học dân gian Việt Nam; một số thể loại đặc biệt của văn học dân gian các dân tộc ít người; khả năng ứng dụng một số thành ngữ, tục ngữ tiếng Việt vào cuộc sống thực tế, nói năng, giao tiếp hàng ngày

\subsubsection{Các học phần tự chọn}

\section{Nhóm các học phần về văn hoá, xã hội, kinh tế}

\section{(44) ASEAN và quan hệ Việt Nam - ASEAN (2 tín chỉ)}

Điều kiện tiên quyết: Sinh viên đã tích luỹ các học phần: Tiếng Việt trung cấp, nâng cao, học thuật. Sinh viên cũng phải tích lũy học phần Tiến trình lịch sử Việt Nam.

Học phần này giúp sinh viên hiểu biết về:

- Hiệp hội các quốc gia Đông Nam Á (Association of Southeast Asian Nations, gọi tắt là ASEAN), một trong những tổ chức quốc tế khu vực thành công nhất trong các nước đang phát triển, năng động và đóng góp tích cực vào quá trình hội nhập quốc tế.

- Quan hệ Việt Nam - ASEAN.

\section{(45) Các đặc trưng sinh thái môi trường Việt Nam (2 tín chỉ)}

Điều kiện tiên quyết: Sinh viên đã tích luỹ các học phần: Tiếng Việt trung cấp, nâng cao Sinh viên là Việt kiều và người nước ngoài phải tích luỹ các học phần: Tiếng Việt trung cấp, nâng cao, học thuật.

Môn học giới thiệu những kiến thức cơ bản về môi trường, sinh thái, mối quan hệ giữa tài nguyên và môi trường sinh thái, cân bằng sinh thái, phát triển bền vững.

Môn học cũng cung cấp khái quát các tài nguyên trên thế giới và Việt Nam, nguyên nhân của việc suy thoái tài nguyên, môi trường,...

\section{(46) Địa lý và cư dân các nước Đông Nam Á (2 tín chỉ)}

Điều kiện tiên quyết: Sinh viên đã luỹ các học phần: Tiếng Việt trung cấp, nâng cao, học thuật. Sinh viên cũng phải tích lũy học phần Địa lý Việt Nam: tự nhiên, nhân văn, kinh tế.

Học phần này giới thiệu khái quát về địa lý Đông Nam Á, tài nguyên tự nhiên, kinh tế, nhân văn; phân tích mối quan hệ giữa tự nhiên và nhân văn, những yếu tố thuận lợi và khó khăn ảnh hưởng đến sự phát triển kinh tế - xã hội các nước Đông Nam Á

\section{(47) Văn hoá bảo đảm đời sống của người Việt (2 tín chỉ)}

Điều kiện tiên quyết: Sinh viên đã tích luỹ các học phần: Tiếng Việt trung cấp, nâng cao, học thuật. Sinh viên cũng phải tích lũy học phần Cơ sở văn hoá Việt Nam.

Học phần giới thiệu về lý thuyết Văn hoá bảo đảm đời sống (Life-sustaining Culture) và Văn hoá bảo đảm đời sống của người Việt.

Văn hoá bảo đảm đời sống của người Việt thể hiện dấu ấn văn hoá riêng của ba miền: Bắc, Trung, Nam cũng như quá trình giao lưu tiếp biến văn hoá (acculturation) về nhà ở, trang phục, ẩm thực giữa người Việt và các dân tộc mà người Việt tiếp xúc.

Văn hoá bảo đảm đời sống giúp nhận diện đặc trưng văn hoá của tộc người, của vùng văn hoá, của quốc gia, khu vực..., giúp hiểu được giá trị văn hoá vật thể và phi vật thể và vấn đề bảo vệ di sản văn hoá dân tộc.

\section{(48) Văn hoá ứng xử Việt Nam (2 tín chỉ)}

Điều kiện tiên quyết: Sinh viên đã tích luỹ các học phần: Tiếng Việt trung cấp, nâng cao, học thuật. Sinh viên cũng phải tích luỹ học phần Cơ sở văn hoá Việt Nam.

Môn học gồm những nội dung chính: Khái niệm về văn hoá và văn hoá ứng xử; Các đặc điểm cơ bản trong văn hoá ứng xử của người Việt Nam (ảnh hưởng Nho giáo, ảnh hưởng văn hoá phương Tây, văn hoá làng xã có tính bản địa, văn hoá mang đậm triết lý âm dương...); Văn hoá ứng xử trong phạm vi gia đình (trong quan hệ vợ chồng, trong quan hệ bố mẹ - con cái, trong quan hệ anh chị em...); Văn hoá ứng xử với môi trường thiên nhiên; Văn hoá ứng xử trong giao tiếp.

\section{(49) Văn hoá Đông Nam Á (2 tín chỉ)}

Điều kiện tiên quyết: Sinh viên đã tích luỹ các học phần: Tiếng Việt trung cấp, nâng cao, học thuật. Sinh viên cũng phải tích luỹ học phần Cở sở văn hoá Việt Nam.

Môn học trang bị cho sinh viên những kiến thức về:

- Văn hoá Đông Nam Á thời tiền sử và sơ sử, gồm Đông Nam Á trên con đường phát triển của lịch sử loài người, Văn hoá Chopper và con đường phát triển đồ đá cũ ở ĐNÁ, Văn hoá Hòa Bình ở Đông Nam Á và sự xuất hiện của nông 
nghiệp, Hậu kỳ đá mới ở Đông Nam Á và sơ đồ các cuộc thiên di của R. Heine Geldern. +Vấn đề trung tâm luyện kim và thời Sơ sử ở Đông Nam Á.

- Văn hoá Đông Nam Á 10 thế kỷ đầu công nguyên: Ảnh hưởng văn hoá Ấn Độ và Trung Hoa; Sự hình thành các quốc gia ở Đông Nam Á; Sự du nhập của Hindu giáo, Phật giáo và Nho giáo vào Đông Nam Á; Nghệ thuật kiến trúc và điêu khắc.

- Văn hoá Đông Nam Á từ thế kỷ 10 đến thế kỷ 19: Sự hình thành các quốc gia ở Đông Nam Á (Đại Việt, Champa, Angkor, Lan Xang, Ayuthaya, Các quốc gia hải đảo); Sự phát triển của Hindu giáo, Phật giáo và Nho giáo và sự du nhập của đạo Islam và đạo Kitô ở Đông Nam Á qua những công trình kiến trúc và điêu khắc; Nghệ thuật kiến trúc và điêu khắc; Giao lưu văn hoá ở các nước Đông Nam Á

\section{(50) Các dân tộc ở Việt Nam (2 tín chỉ)}

Điều kiện tiên quyết: Sinh viên đã tích luỹ các học phần: Tiếng Việt trung cấp, nâng cao, học thuật. Sinh viên cũng phải tích luỹ học phần Nhân học đại cương

Môn học giới thiệu kiến thức cơ bản về các dân tộc ở Việt Nam theo các vấn đề: đặc điểm cộng đồng các dân tộc Việt Nam; văn hoá cộng đồng các dân tộc Việt Nam; các dân tộc người Việt Nam trong sự nghiệp xây dựng và bảo vệ Tổ quốc Việt Nam.

\section{(51) Khảo cổ học Việt Nam (2 tín chỉ)}

Điều kiện tiên quyết: Sinh viên đã tích luỹ các học phần: Tiếng Việt trung cấp, nâng cao, học thuật. Sinh viên cũng phải tích luỹ học phần Nhân học đại cương, Tiến trình lịch sử Việt Nam.

Môn học giới thiệu một cách hệ thống toàn bộ lịch sử phát hiện và nghiên cứu các nền văn hoá khảo cổ ở Việt Nam các nền văn hoá thời đại đồ đá, các nền văn hoá thời đại đồ đồng, các nền văn hoá thời đại đồ sắt, văn hoá Đông Sơn, văn hoá Đại Việt, văn hoá Sa Huỳnh, văn hoá Óc Eo...

\section{Nhóm các học phần về khoa học Ngữ văn (Philology Module)}

\section{(52) Các phương tiện liên kết và soạn thảo văn bản (2 tín chỉ)}

Điều kiện tiên quyết: Sinhvie6n đã tích luỹ các học phần: Tiếng Việt trung cấp, nâng cao, học thuật. Sinh viên cũng phải tích lũy học phần về Ngữ pháp tiếng Việt.

Học phần cung cấp những kiến thức căn bản về văn bản tiếng Việt (các phương tiện liên kết trong câu ghép; cấu tạo đoạn văn và các loại đoạn văn; phương thức tổ chức một văn bản; các phương thức lập luận, cách thức tóm tắt và xây dựng đề cương một văn bản) và khả năng ứng dụng vào hoạt động thực tiễn. Giúp sinh viên có khả năng tóm tắt và xây dựng đề cương cũng như khả năng soạn thảo một văn bản hành chính thông thường.

\section{(53) Lý thuyết dịch (2 tín chỉ)}

Điều kiện tiên quyết: Sinh viên đã tích luỹ các học phần: Tiếng Việt trung cấp, nâng cao, học thuật. Sinh viên cũng phải tích lũy học phần về Dẫn luận Ngôn ngữ học.

Học phần cung cấp các lý thuyết dịch và những vấn đề liên quan: Giới thiệu một cách khái quát về khái niệm dịch, các lý thuyết dịch thuật hiện hành, các yếu tố cấu thành và tác động đến quá trình chuyển dịch. Ngoài ra, trong học phần này, sinh viên sẽ thực hành chuyển dịch để tìm hiểu kỹ hơn các vấn đề liên quan đến dịch thuật (kiến thức ngôn ngữ và kiến thức phi ngôn ngữ).

\section{(54) Ngữ âm tiếng Việt thụ̣c hành (2 tín chỉ)}

Điều kiện tiên quyết: Sinh viên đã học qua các học phần: Tiếng Việt trung cấp, Tiếng Việt nâng cao, Tiếng Việt học thuật. Sinh viên cũng phải tích lũy học phần Dẫn luận Ngôn ngữ học.

Học phần giúp sinh viên thực hành những kiến thức cơ bản của ngữ âm tiếng Việt (hệ thống ngữ âm tiếng Việt, cấu trúc âm tiết, các tiểu hệ thống âm vị); luyện cho sinh viên phát âm chuẩn xác tiếng Việt và cách phân tích dữ liệu ngữ âm tiếng Việt.

\section{(55) Phương ngữ tiếng Việt (2 tín chỉ)}

Điều kiện tiên quyết: Sinh viên đã học qua các học phần: Tiếng Việt trung cấp, Tiếng Việt nâng cao, Tiếng Việt học thuật. Sinh viên cũng phải tích lũy học phần Dẫn luận Ngôn ngữ học.

Học phần giới thiệu về khái niệm tiếng chuẩn, chuẩn hoá, phương ngữ và tình hình nghiên cứu phương ngữ tiếng Việt trình bày những khác biệt có tính qui luật và những khác biệt phi qui luật giữa các phương ngữ tiếng Việt, từ đó giúp sinh viên hiểu rõ hơn về tiếng Việt và những vấn đề liên quan.

\section{(56) Phương pháp giảng dạy ngoại ngữ (2 tín chỉ)}

Điều kiện tiên quyết: Sinh viên đã học qua các học phần: Tiếng Việt trung cấp, Tiếng Việt nâng cao, Tiếng Việt học thuật. Sinh viên cũng phải tích lũy học phần Dẫn luận Ngôn ngữ học.

Học phần này cung cấp những kiến thức cơ bản cho sinh viên những vấn đề liên quan đến phương pháp giảng dạy ngoại ngữ, cách giảng dạy các kỹ năng Nghe - Nói - Đọc - Viết, cách biên soạn giáo án và quản lý lớp học ngoại ngữ. Môn học này còn giúp sinh viên có thể áp dụng để giảng dạy tiếng Việt như một ngoại ngữ.

\section{(57) Tiếng Việt báo chí (2 tín chỉ)}

Điều kiện tiên quyết: Sinh viên đã học qua các học phần: Tiếng Việt trung cấp, Tiếng Việt nâng cao, Tiếng Việt học thuật. Sinh viên cũng phải tích lũy học phần Dẫn luận Ngôn ngữ học. 
Học phần này nhằm giúp sinh viên hiểu đặc điểm của phong cách báo chí tiếng Việt, nâng cao khả năng đọc hiểu báo chí tiếng Việt. Sinh viên sẽ học trực tiếp trên số báo mới nhất những bài thuộc phần thực hành đọc báo từ dễ đến khó

\section{(58) Tiếng Việt thương mại (2 tín chỉ)}

Điều kiện tiên quyết: Sinh viên đã học qua các học phần: Tiếng Việt trung cấp, Tiếng Việt nâng cao, Tiếng Việt học thuật. Sinh viên cũng phải tích lũy học phần Dẫn luận Ngôn ngữ học.

Học phần trang bị kiến thức cơ bản về giao tiếp trong môi trường thương mại, trong công ty bằng tiếng Việt, trang bi kiến thức cơ bản về môi trường thương mại Việt Nam, giúp sinh viên có khả năng sử dụng và xử lý một số văn bản thương mại tại Việt Nam và cung cấp từ vựng chuyên ngành tiếng Việt thương mại.

Môn học giúp cho sinh viên học về cách giới và tự giới thiệu về các cá nhân, các vị trí trong công ty, cách thức giao tiếp giao dịch qua điện thoại, kế hoạch, lịch công tác trong ngày; các vị trí và mô tả công việc trong công ty.

\section{(59) Từ vựng học tiếng Việt thực hành (2 tín chỉ)}

Điều kiện tiên quyết: Sinh viên đã học qua các học phần: Tiếng Việt trung cấp, Tiếng Việt nâng cao, Tiếng Việt học thuật. Sinh viên cũng phải tích lũy học phần Dẫn luận Ngôn ngữ học.

Học phần giúp sinh viên nắm kiến thức cơ bản trong thực hành từ vựng tiếng Việt, các biến đổi ngữ nghĩa trong từ, các lớp từ và cách dùng từ tiếng Việt; luyện cho sonh viên khả năng sử dụng tốt các lớp từ vựng - ngữ nghĩa tiếng Việt.

\section{(60) Lịch sử tiếng Việt (2 tín chỉ)}

Điều kiện tiên quyết: Sinh viên đã học qua các học phần: Tiếng Việt trung cấp, Tiếng Việt nâng cao, Tiếng Việt học thuật. Sinh viên cũng phải tích lũy học phần Dẫn luận Ngôn ngữ học.

Học phần giới thiệu nguồn gốc tiếng Việt và các quan hệ về nguồn gốc, quan hệ tiếp xúc giữa tiếng Việt với các ngôn ngữ khác trong quá trình phát triển lịch sử. Ngoài ra, học phần còn giới thiệu khái quát các giai đoạn diễn biến chính của tiếng Việt từ trước tới nay.

\section{(61) Phong cách học tiếng Việt (2 tín chỉ)}

Điều kiện tiên quyết: Sinh viên đã học qua các học phần: Tiếng Việt trung cấp, Tiếng Việt nâng cao, Tiếng Việt học thuật. Sinh viên cũng phải tích lũy học phần Dẫn luận Ngôn ngữ học.

Đây là học phần cung cấp các lý thuyết đại cương về phong cách học cũng như cấu trúc tu từ của một ngôn ngữ cụ thể, giúp sinh viên hiểu sâu hơn các đặc điểm bản chất của ngôn ngữ mình theo học.

\section{(62) Từ Hán - Việt (2 tín chỉ)}

Điều kiện tiên quyết: Sinh viên đã học qua các học phần: Tiếng Việt trung cấp, Tiếng Việt nâng cao, Tiếng Việt học thuật. Sinh viên cũng phải tích lũy học phần Dẫn luận Ngôn ngữ học.

Học phần này nhằm giúp sinh viên nắm được một số kiến thức căn bản về lịch sử từ gốc Hán trong tiếng Việt nói chung và từ Hán Việt nói riêng, cách cấu tạo từ Hán Việt. Ngoài ra học phần còn chỉ ra nguyên nhân và một số lỗi thường thấy khi sử dụng từ Hán Việt của người Việt.

\section{(63) Ngôn ngũ̃ học đối chiếu (2 tín chỉ)}

Điều kiện tiên quyết: Sinh viên đã học qua các học phần: Tiếng Việt trung cấp, Tiếng Việt nâng cao, Tiếng Việt học thuật. Sinh viên cũng phải tích lũy học phần Dẫn luận Ngôn ngữ học.

Học phần cung cấp những kiến thức cơ bản về ngôn ngữ học đối chiếu: các nguyên tắc và phương pháp đối chiếu ngôn ngữ; thủ pháp đối chiếu.

Học phần cũng luyện cho sinh viên thực hành đối chiếu tiếng Việt với một số ngôn ngữ khác (cùng và khác loại hình).

\section{(64) Truyện ngắn Việt Nam hiện đại (2 tín chỉ)}

Điều kiện tiên quyết: Sinh viên đã học qua các học phần: Tiếng Việt trung cấp, Tiếng Việt nâng cao, Tiếng Việt học thuật. Sinh viên cũng phải tích lũy học phần Đại cương văn học Việt Nam.

Học phần này nhằm giúp sinh viên nắm được một số kiến thức căn bản về lịch sử văn học Việt Nam có tính tổng quát; giới thiệu các tác giả trẻ tiêu biểu của văn học đương đại, nâng cao trình độ đọc hiểu bằng tiếng Việt.

\section{(65) Thực tập, thực tế (4 tín chỉ)}

- Đối với sinh viên Việt Nam: Sinh viên đến thực tập, thực tế tại các cơ sở du lịch, ngoại giao, giáo dục,... để có điều kiện vận dụng những kiến thức về Việt Nam học đã học vào công việc.

- Đối với sinh viên là Việt kiều và người nước ngoài: Sinh viên đến thực tập, thực tế tại các cơ sở tại Việt nam hoặc nước ngoài có mối quan hệ với Việt Nam để có điều kiện thực hành tiếng Việt và vận dụng những kiến thức Việt Nam học đã học vào thực tế công việc.

\section{(66) Khoá luận tốt nghiệp (10 tín chỉ)}

Khoá luận tốt nghiệp là một học phần đặc biệt, tương đương với 10 tín chỉ.

Những sinh viên đủ điều kiện về điểm và có nhu cầu làm khoá luận tốt nghiệp đăng ký vào cuối học kỳ 8 và được Khoa phân công người hướng dẫn và hướng đề tài. Khoá luận sẽ được chấm bởi Hội đồng do Khoa thành lập, trong đó có tối thiểu 2 phản biện đọc, nhận xét và cho điểm. Sinh viên làm khoá luận tốt nghiệp được miễn học 10 tín chỉ tự chọn trong khối Kiến thức chuyên sâu của ngành.

\section{Danh sách đội ngũ giảng viên thực hiện chương trình}

Khoa Việt Nam học hiện có 31 cán bộ cơ hữu, trong đó đội ngũ cán bộ giảng dạy có 4 Phó Giáo sư - Tiến sĩ, 11 Tiến sĩ 14 Thạc sĩ, cán bộ giảng dạy là Giảngviên chính là 14 người. Ngoài ra, hàng năm thường xuyên có khoảng 10 giảng 
viên thuộc các đơn vị khác trong Trường được mời tham gia giảng dạy chương trình.

* Danh sách giảng viên cơ hữu:

\begin{tabular}{|c|c|c|c|c|c|c|}
\hline TT & Họ và tên & $\begin{array}{l}\text { Năm } \\
\text { sinh }\end{array}$ & $\begin{array}{l}\text { Văn bằng } \\
\text { cao nhất, } \\
\text { ngành đào } \\
\text { tạo }\end{array}$ & $\begin{array}{l}\text { Năm } \\
\text { được } \\
\text { cấp } \\
\text { bằng }\end{array}$ & $\begin{array}{l}\text { Kinh nghiệm } \\
\text { giảng dạy }\end{array}$ & $\begin{array}{c}\text { Môn học } \\
\text { sẽ giảng } \\
\text { dạy }\end{array}$ \\
\hline 1 & $\begin{array}{l}\text { Phan Thái } \\
\text { Bình }\end{array}$ & 1980 & $\begin{array}{lr}\text { Thạc } & \text { sĩ } \\
\text { Văn } & \text { hoá } \\
\text { học } & \end{array}$ & 2009 & 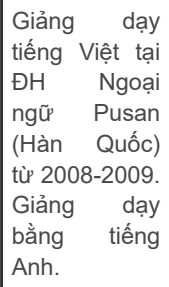 & $\begin{array}{ll}\text { Văn } & \text { hoá } \\
\text { ứng xử Việt } \\
\text { Nam }\end{array}$ \\
\hline 2 & $\begin{array}{l}\text { Lê Khắc } \\
\text { Cường }\end{array}$ & 1960 & $\begin{array}{l}\text { Tiến sĩ } \\
\text { Ngôn ngữ } \\
\text { học }\end{array}$ & 2000 & & $\begin{array}{ll}\text { Dẫn } & \text { luận } \\
\text { Ngôn } & \text { ngữ } \\
\text { học, } & \text { Tiếng } \\
\text { Việt r qua } & \text { báo chí }\end{array}$ \\
\hline 3 & $\begin{array}{l}\text { Đinh Thị } \\
\text { Dung }\end{array}$ & 1961 & $\begin{array}{l}\text { Tiến sĩ Văn } \\
\text { hoá học }\end{array}$ & 2001 & & $\begin{array}{ll}\text { Cơ sở } & \text { văn } \\
\text { hoá } & \text { Việt } \\
\text { Nam, } & \text { Lịch } \\
\text { sử } & \text { văn } \\
\text { minh } & \text { thế } \\
\text { giới } & \end{array}$ \\
\hline 4 & $\begin{array}{l}\text { Đào Mục } \\
\text { Đích }\end{array}$ & 1968 & $\begin{array}{lr}\text { Thạc } & \text { sĩ } \\
\text { Ngôn } & \text { ngữ } \\
\text { học } & \text { so } \\
\text { sánh } & \end{array}$ & 2001 & $\begin{array}{l}\text { Giảng dạy } \\
\text { tiếng Việt }\end{array}$ & $\begin{array}{l}\text { Tiếng Việt - } \\
\text { Nghe }\end{array}$ \\
\hline 5 & $\begin{array}{l}\text { Bùi Thị } \\
\text { Phương } \\
\text { Chi }\end{array}$ & 1963 & $\begin{array}{lr}\text { Thạc } & \text { sĩ } \\
\text { Ngôn } & \text { ngữ } \\
\text { Nga } & \\
\text {-Slavơ } & \end{array}$ & 1999 & & $\begin{array}{l}\text { Tiếng Việt - } \\
\text { Nghe }\end{array}$ \\
\hline 6 & $\begin{array}{l}\text { Trần Thị } \\
\text { Minh Giới }\end{array}$ & 1958 & $\begin{array}{ll}\text { Thạc } & \text { sĩ } \\
\text { Văn học } & \end{array}$ & 1996 & $\begin{array}{l}\text { Giảng dạy } \\
\text { tiếng Việt tại } \\
\text { ĐH } \\
\text { Ritsumeikan } \\
\text { Asia Pacific } \\
\text { (Nhật Bản) } \\
\text { trong các học } \\
\text { kỳ Mùa Thu } \\
\text { từ 2003-2006. } \\
\text { Giảng dạy } \\
\text { bằng tiếng } \\
\text { Anh. }\end{array}$ & $\begin{array}{ll}\text { Tiếng } & \text { Việt - } \\
\text { Nói; } & \text { Văn } \\
\text { học } & \text { Việt } \\
\text { Nam } & \end{array}$ \\
\hline 7 & $\begin{array}{l}\text { Nguyễn } \\
\text { Thị Thanh } \\
\text { Hà }\end{array}$ & 1979 & $\begin{array}{l}\text { Thạc sĩ } \\
\text { Nhân học }\end{array}$ & 2007 & & $\begin{array}{l}\text { Phương } \\
\text { pháp học } \\
\text { đại } \quad \text { học; } \\
\text { Văn hoá } \\
\text { Việt Nam }\end{array}$ \\
\hline 8 & $\begin{array}{lr}\text { Bùi } \quad \text { Thị } \\
\text { Duyên Hải }\end{array}$ & 1980 & $\begin{array}{l}\text { Thạc sĩ } \\
\text { Châu Á học }\end{array}$ & 2009 & & $\begin{array}{l}\text { Văn hoá } \\
\text { bảo đảm } \\
\text { đời sống ở } \\
\text { Việt Nam, } \\
\text { Tiếng Việt - } \\
\text { Nói }\end{array}$ \\
\hline 9 & $\begin{array}{l}\text { Nguyễn } \\
\text { Thị Ngọc } \\
\text { Hân }\end{array}$ & 1960 & $\begin{array}{l}\text { Tiến } \quad \text { sĩ } \\
\text { Ngôn ngữ } \\
\text { học }\end{array}$ & 2005 & \begin{tabular}{|lr} 
Giảng dạy \\
tiếng Việt tại \\
ĐH Ngoại \\
ngữ Kanda \\
(Nhật & Bản) từ \\
$2006-2009$. \\
Giảng dạy \\
bằng tiếng \\
Anh.
\end{tabular} & $\begin{array}{l}\text { Tiếng Việt - } \\
\text { Đọc - Viết; } \\
\text { Ngũ pháp } \\
\text { tiếng Việt }\end{array}$ \\
\hline 10 & $\begin{array}{lr}\text { Lêr } \quad \text { Thị } \\
\text { Minh Hằng }\end{array}$ & 1961 & $\begin{array}{l}\text { Tiến } \quad \text { sĩ } \\
\text { Ngôn ngữ } \\
\text { học }\end{array}$ & 2006 & $\begin{array}{l}\text { Giảng dạy } \\
\text { tiếng Việt tại } \\
\text { ĐH Thương } \\
\text { mại Nagoya } \\
\text { (Nhật Bản) từ }\end{array}$ & $\begin{array}{ll}\text { Tiếng } & \text { Việt - } \\
\text { Viết; } & \text { Ngữ } \\
\text { pháp } & \text { tiếng } \\
\text { Việt } & \end{array}$ \\
\hline
\end{tabular}




\begin{tabular}{|c|c|c|c|c|c|c|}
\hline TT & Họ và tên & $\begin{array}{l}\text { Năm } \\
\text { sinh }\end{array}$ & $\begin{array}{c}\text { Văn bằng } \\
\text { cao nhất, } \\
\text { ngành đào } \\
\text { tạo }\end{array}$ & $\begin{array}{l}\text { Năm } \\
\text { được } \\
\text { cấp } \\
\text { bằng }\end{array}$ & $\begin{array}{l}\text { Kinh nghiệm } \\
\text { giảng dạy }\end{array}$ & $\begin{array}{l}\text { Môn học } \\
\text { sẽ giảng } \\
\text { dạy }\end{array}$ \\
\hline & & & & & 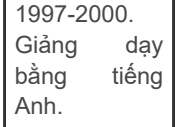 & \\
\hline 11 & $\begin{array}{l}\text { Huỳnh } \\
\text { Công Hiển }\end{array}$ & 1964 & \begin{tabular}{|lr} 
Thạc & sĩ \\
Ngôn & ngữ \\
học & so \\
sánh &
\end{tabular} & 2003 & & $\begin{array}{l}\text { Tiếng Việt - } \\
\text { Nói - Đọc }\end{array}$ \\
\hline 12 & $\begin{array}{l}\text { Trần Thị } \\
\text { Hoa }\end{array}$ & 1956 & $\begin{array}{lr}\text { Tiến } & \text { sĩ } \\
\text { Ngôn } & \text { ngữ } \\
\text { học } & \end{array}$ & 2005 & & $\begin{array}{l}\text { Tiếng Việt - } \\
\text { Nghe, } \\
\text { Các } \\
\text { phương tiện } \\
\text { liên kết và } \\
\text { soạn thảo } \\
\text { tiêng Việt }\end{array}$ \\
\hline 13 & $\begin{array}{l}\text { Nguyễn } \\
\text { Văn Huệ }\end{array}$ & 1952 & $\begin{array}{ll}\text { PGS, } & \text { Tiến } \\
\text { sĩ } & \text { Ngôn } \\
\text { ngữ học } & \text { so } \\
\text { sánh } & \end{array}$ & 2006 & \begin{tabular}{|lr} 
Giảng & dạy \\
tiếng & Việt \\
Đại \\
nH & Ngoại \\
ngữ & Tokyo \\
(Nhật & Bản) từ \\
$1991-1995$ & và \\
ĐH & \\
Ritsumeikan \\
Asia & Pacific \\
từ 2004-2005. \\
Giảng & dạy \\
bằng & tiếng \\
Anh và & tiếng \\
Nhật &
\end{tabular} & $\begin{array}{l}\text { Lịch sử } \\
\text { tiếng Việt; } \\
\text { Phương } \\
\text { pháp giảng } \\
\text { dạy ngoại } \\
\text { ngữ; Ngôn } \\
\text { ngữ học Đối } \\
\text { chiếu }\end{array}$ \\
\hline 14 & $\begin{array}{l}\text { Võ Thanh } \\
\text { Hương }\end{array}$ & 1963 & $\begin{array}{lr}\text { Thạc } & \text { sĩ } \\
\text { Ngôn } & \text { ngữ } \\
\text { học } & \text { so } \\
\text { sánh } & \end{array}$ & 2004 & & $\begin{array}{l}\text { Tiếng Việt - } \\
\text { Đọc }\end{array}$ \\
\hline 15 & $\begin{array}{l}\text { Nguyễn } \\
\text { Thu Lan }\end{array}$ & 1978 & $\begin{array}{l}\text { Thạc sĩ } \\
\text { Quan hệ } \\
\text { Quốc tế }\end{array}$ & 2008 & & \begin{tabular}{|lr} 
Khu vực \\
học và Việt \\
Nam học; \\
ASEAN và \\
quan hệ \\
Việt Nam - \\
ASEAN
\end{tabular} \\
\hline 16 & $\begin{array}{l}\text { Nguyễn } \\
\text { Tuấn } \\
\text { Nghĩa }\end{array}$ & 1984 & $\begin{array}{l}\text { Thạc sĩ } \\
\text { Châu Á học }\end{array}$ & 2013 & & $\begin{array}{l}\text { Phương } \\
\text { pháp học } \\
\text { đại học, } \\
\text { ASEAN và } \\
\text { quan hệ } \\
\text { VN-ASEAN }\end{array}$ \\
\hline 17 & $\begin{array}{l}\text { Trần Trọng } \\
\text { Nghĩa }\end{array}$ & 1975 & $\begin{array}{l}\text { Thạc } \quad \text { sĩ } \\
\text { Ngôn ngữ } \\
\text { học }\end{array}$ & 2011 & & $\begin{array}{l}\text { Tiếng Việt - } \\
\text { Nghe; } \\
\text { Ngữ pháp } \\
\text { tiếng Việt }\end{array}$ \\
\hline 18 & $\begin{array}{l}\text { Trần Thị } \\
\text { Mai Nhân }\end{array}$ & 1970 & $\begin{array}{l}\text { Tiến sĩ Văn } \\
\text { học }\end{array}$ & 2008 & & $\begin{array}{lr}\text { Văn } & \text { học } \\
\text { Việt } & \text { Nam; } \\
\text { Văn } & \text { học } \\
\text { dân } & \text { gian } \\
\text { Việt } & \text { Nam }\end{array}$ \\
\hline 19 & $\begin{array}{l}\text { Nguyễn } \\
\text { Vân Phổ }\end{array}$ & 1963 & $\begin{array}{|lr|}\text { Tiến } & \text { sĩ } \\
\text { Ngôn } & \text { ngữ } \\
\text { học } & \text { so } \\
\text { sánh } & \end{array}$ & 2007 & & \begin{tabular}{|lr} 
Tiếng & Việt - \\
Viết; & Ngữ \\
pháp & tiếng \\
Việt &
\end{tabular} \\
\hline 20 & $\begin{array}{l}\text { Nguyễn } \\
\text { Thanh } \\
\text { Phong }\end{array}$ & 1974 & $\begin{array}{lr}\text { Thạc } & \text { sĩ } \\
\text { Ngôn } & \text { ngữ } \\
\text { học } & \text { so } \\
\text { sánh } & \end{array}$ & 2001 & $\begin{array}{lr}\text { Giảng } & \text { dạy } \\
\text { tiếng } & \text { Việt } \\
\text { tại } \\
\text { nH } & \text { Ngoại } \\
\text { ngữ } & \text { Hankuk } \\
\text { (Hàn } & \text { Quốc) } \\
\text { từ } 2005-2008 . \\
\text { Giảng } & \text { dạy } \\
\text { bằng } & \text { tiếng }\end{array}$ & $\begin{array}{l}\text { Tiếng Việt - } \\
\text { Nói - Đọc }\end{array}$ \\
\hline
\end{tabular}




\begin{tabular}{|c|c|c|c|c|c|c|}
\hline TT & Họ và tên & $\begin{array}{l}\text { Năm } \\
\text { sinh }\end{array}$ & $\begin{array}{c}\text { Văn bằng } \\
\text { cao nhất, } \\
\text { ngành đào } \\
\text { tạo }\end{array}$ & $\begin{array}{l}\text { Năm } \\
\text { được } \\
\text { cấp } \\
\text { bằng }\end{array}$ & $\begin{array}{l}\text { Kinh nghiệm } \\
\text { giảng dạy }\end{array}$ & $\begin{array}{l}\text { Môn học } \\
\text { sẽ giảng } \\
\text { dạy }\end{array}$ \\
\hline & & & & & Anh. & \\
\hline 21 & $\begin{array}{l}\text { Nguyễn } \\
\text { Văn Thành }\end{array}$ & 1968 & $\begin{array}{ll}\text { Thạc } & \text { sĩ } \\
\text { Lịch sử } & \end{array}$ & 2001 & & $\begin{array}{l}\text { Lịch sử Việt } \\
\text { Nam; Lịch } \\
\text { sử Kinh tế } \\
\text { Việt Nam }\end{array}$ \\
\hline 22 & $\begin{array}{l}\text { Huỳnh } \\
\text { Đức Thiện }\end{array}$ & 1972 & $\begin{array}{l}\text { Tiến sĩ Lịch } \\
\text { sử }\end{array}$ & 2012 & & $\begin{array}{l}\text { Tiến trình } \\
\text { lịch sử Việt } \\
\text { Nam; Lịch } \\
\text { sử Kinh tế } \\
\text { Việt Nam }\end{array}$ \\
\hline 23 & $\begin{array}{l}\text { Nguyễn } \\
\text { Thanh } \\
\text { Thủy }\end{array}$ & 1965 & $\begin{array}{lr}\text { Thạc } & \text { sĩ } \\
\text { Ngôn } & \text { ngữ } \\
\text { học } & \text { so } \\
\text { sánh } & \end{array}$ & 2003 & & $\begin{array}{lr}\text { Dẫn } & \text { luận } \\
\text { Ngôn } & \text { ngữ } \\
\text { học; } & \text { Từ } \\
\text { vựng } & \text { tiếng } \\
\text { Việt } & \text { thực } \\
\text { hành } & \end{array}$ \\
\hline 24 & $\begin{array}{l}\text { Đinh Lê } \\
\text { Thư }\end{array}$ & 1946 & $\begin{array}{lr}\text { Tiến } & \text { sĩ } \\
\text { Ngôn } & \text { ngữ } \\
\text { học } & \end{array}$ & 1981 & & $\begin{array}{l}\text { Ngữ âm } \\
\text { tiếng Việt, } \\
\text { Tiếng Việt } \\
\text { thương mại }\end{array}$ \\
\hline 25 & $\begin{array}{l}\text { Phan Thị } \\
\text { Yến Tuyết }\end{array}$ & 1952 & $\begin{array}{l}\text { PGS, Tiến } \\
\text { sĩ Dân tộc } \\
\text { học }\end{array}$ & 1992 & & $\begin{array}{l}\text { Văn hoá } \\
\text { Việt Nam; } \\
\text { Văn hoá du } \\
\text { lịch VN; } \\
\text { Văn hoá } \\
\text { đảm bảo } \\
\text { đời sống ở } \\
\text { VN }\end{array}$ \\
\hline 26 & $\begin{array}{l}\text { Trần Thị } \\
\text { Tươi }\end{array}$ & 1984 & $\begin{array}{lr}\text { Thạc } & \text { sĩ } \\
\text { Văn } & \text { học } \\
\text { VN } & \end{array}$ & 2011 & & $\begin{array}{l}\text { Lịch sử văn } \\
\text { học Việt } \\
\text { Nam, } \\
\text { Truyện } \\
\text { ngắn Việt } \\
\text { Nam }\end{array}$ \\
\hline 27 & $\begin{array}{l}\text { Lê Hoàng } \\
\text { Ngọc Yến }\end{array}$ & 1983 & $\begin{array}{l}\text { Thạc sĩ } \\
\text { Châu Á học }\end{array}$ & 2007 & & $\begin{array}{l}\text { Tiếng Việt - } \\
\text { Nghe; } \\
\text { Phương } \\
\text { pháp học } \\
\text { đại học }\end{array}$ \\
\hline 28 & $\begin{array}{l}\text { Nguyễn } \\
\text { Thị Hoàng } \\
\text { Yến }\end{array}$ & 1964 & $\begin{array}{lr}\text { Thạc } & \text { sĩ } \\
\text { Ngôn } & \text { ngữ } \\
\text { học } & \text { so } \\
\text { sánh } & \end{array}$ & 1998 & $\begin{array}{l}\text { Giảng dạy } \\
\text { tiếng Việt tại } \\
\text { ĐH Ngoại } \\
\text { ngữ Kanda } \\
\text { (Nhật Bản) từ } \\
2003-2006 . \\
\text { Giảng dạy } \\
\text { bằng tiêng } \\
\text { Anh. }\end{array}$ & $\begin{array}{l}\text { Tiếng Việt - } \\
\text { Nghe; } \\
\text { Phong cách } \\
\text { học tiếng } \\
\text { Việt; Truyện } \\
\text { ngắn VN } \\
\text { hiện đại }\end{array}$ \\
\hline 29 & $\begin{array}{l}\text { Trần Thủy } \\
\text { Vịnh }\end{array}$ & 1964 & $\begin{array}{l}\text { Tiến } \\
\text { Ngôn } \\
\text { học }\end{array}$ & 2006 & $\begin{array}{l}\text { Giảng dạy } \\
\text { tiếng Việt tại } \\
\text { Hàn Quốc ( } 1 \\
\text { năm, giảng } \\
\text { dạy bằng } \\
\text { tiếng Anh) }\end{array}$ & $\begin{array}{l}\text { Tiếng Việt - } \\
\text { Nói }\end{array}$ \\
\hline
\end{tabular}

11. Danh sách Cố vấn học tập

- ThS. Nguyễn Thị Hoàng Yến

- ThS. Nguyễn Văn Thành

12. Cơ sở vật chất phục vụ học tập:

12.1 Phòng thí nghiệm và hệ thống thiết bị thí nghiệm chính;

\begin{tabular}{|c|c|c|c|}
\hline TT & $\begin{array}{c}\text { Tên phòng thí nghiệm, địa } \\
\text { điểm thực tập }\end{array}$ & Đơn vị chủ quản & Ghi chú \\
\hline & & & \\
\hline
\end{tabular}

12.2 Thư viện: Ngoài Thư viện của Trường Đại học KHXH-NV, Khoa có 01 tủ sách nhỏ phục vụ cho việc học tập 
nghiên cứu của sinh viên Khoa (khoảng 4.00 đầu sách)

12.3 Giáo trình, tập bài giảng

\begin{tabular}{|c|c|c|c|c|c|c|c|}
\hline STT & $\begin{array}{l}\text { Tên môn } \\
\text { học }\end{array}$ & $\begin{array}{l}\text { Tên giáo trình, } \\
\text { tập bài giảng }\end{array}$ & Tên tác giả & Nhà xuất bản & $\begin{array}{l}\text { Năm } \\
\text { xuất } \\
\text { bản }\end{array}$ & Địa chỉ website & $\begin{array}{c}\text { Hiện } \\
\text { trạng[] }\end{array}$ \\
\hline \multirow[t]{2}{*}{1} & \multirow[t]{2}{*}{$\begin{array}{l}\text { Tiếng Việt } \\
\text { trung cấp } \\
\text { (Nghe - nói } \\
\text { - đọc - viết) }\end{array}$} & $\begin{array}{l}\text { Giáo trình tiếng } \\
\text { Việt cho người } \\
\text { nước ngoài, tập } \\
1\end{array}$ & $\begin{array}{lr}\text { Nguyễn } & \text { Văn } \\
\text { Huệ (cb), } & \text { Trần } \\
\text { Thị Minh } & \text { Giới, } \\
\text { Nguyễn } & \text { Thị } \\
\text { Ngọc } & \text { Hân, } \\
\text { Thạch } & \text { Ngọc } \\
\text { Minh } & \end{array}$ & $\begin{array}{l}\text { ĐHQG } \\
\text { TP.HCM }\end{array}$ & 2008 & & Đã có \\
\hline & & $\begin{array}{l}\text { Từ điển ngũ } \\
\text { pháp tiếng Việt } \\
\text { cơ bản (Song } \\
\text { ngữ Việt - Anh) }\end{array}$ & 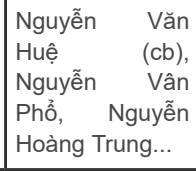 & $\begin{array}{l}\text { ĐHQG } \\
\text { TP.HCM }\end{array}$ & 2003 & & Đã có \\
\hline \multirow[t]{2}{*}{2} & \multirow[t]{2}{*}{$\begin{array}{l}\text { Tiếng Việt } \\
\text { nâng cao } \\
\text { (Nghe }- \text { nói } \\
\text { - đọc }- \text { viết) }\end{array}$} & $\begin{array}{l}\text { Giáo trình tiếng } \\
\text { Việt cho người } \\
\text { nước ngoài, tập } \\
2\end{array}$ & $\begin{array}{lr}\text { Nguyễn } & \text { Văn } \\
\text { Huệ (cb), } & \text { Trần } \\
\text { Thị Minh } & \text { Giới, } \\
\text { Nguyễn } & \text { Thị } \\
\text { Ngọc } & \text { Hân, } \\
\text { Thạch } & \text { Ngọc } \\
\text { Minh } & \end{array}$ & $\begin{array}{l}\text { ĐHQG } \\
\text { TP.HCM }\end{array}$ & 2008 & $\begin{array}{l}\text { vtv.com.vn; } \\
\text { vov.org.vn; } \\
\text { sucsongmoi.com.vn }\end{array}$ & Đã có \\
\hline & & $\begin{array}{l}\text { Tì̀ diển ngũ } \\
\text { pháp tiếng Việt } \\
\text { co bản (Song } \\
\text { ngữ Việt - Anh) }\end{array}$ & \begin{tabular}{|lr} 
Nguyễn & Văn \\
Huệ & (cb), \\
Nguyễn & Vân \\
Phổ, & Nguyễn \\
Hoàng & Trung...
\end{tabular} & $\begin{array}{l}\text { ĐHQG } \\
\text { TP.HCM }\end{array}$ & 2003 & $\begin{array}{l}\text { tuoitre.com.vn; } \\
\text { vnexpress.net }\end{array}$ & Đã có \\
\hline \multirow[t]{3}{*}{3} & \multirow[t]{3}{*}{\begin{tabular}{|l} 
Tiếng Việt \\
họcr thuật \\
(Nghe - nói \\
- đọc - viết)
\end{tabular}} & $\begin{array}{l}\text { Giáo trình tiếng } \\
\text { Việt cho người } \\
\text { nước ngoài, tập } \\
3\end{array}$ & $\begin{array}{lr}\text { Nguyễn } & \text { Văn } \\
\text { Huệ (cb), } & \text { Trần } \\
\text { Thị Minh } & \text { Giới, } \\
\text { Nguyễn } & \text { Thị } \\
\text { Ngọc Hân, } & \text { Trần } \\
\text { Thủy Vịnh } & \end{array}$ & Giáo dục & 2003 & $\begin{array}{l}\text { vtv.com.vn; } \\
\text { vov.org.vn; } \\
\text { sucsongmoi.com.vn }\end{array}$ & Đã có \\
\hline & & $\begin{array}{l}\text { Giáo trình tiếng } \\
\text { Việt cho người } \\
\text { nước ngoài, tập } \\
4\end{array}$ & \begin{tabular}{lr} 
Nguyễn & Văn \\
Huệ (cb), & Trần \\
Thị Minh & Giới, \\
Nguyễn & Thị \\
Ngọc Hân, & Trần \\
\multicolumn{2}{|c}{ Thủy Vịnh }
\end{tabular} & Giáo dục & 2004 & $\begin{array}{l}\text { tuoitre.com.vn; } \\
\text { vnexpress.net }\end{array}$ & \\
\hline & & $\begin{array}{l}\text { Từ điển ngũ } \\
\text { pháp tiếng Việt } \\
\text { cơ bản (Song } \\
\text { ngữ Việt }- \text { Anh) }\end{array}$ & \begin{tabular}{|lr} 
Nguyễn & Văn \\
Huệ & $(\mathrm{cb})$, \\
Nguyễn & Vân \\
Phổ, & Nguyễn \\
Hoàng & Trung...
\end{tabular} & $\begin{array}{l}\text { ĐHQG } \\
\text { TP.HCM }\end{array}$ & 2003 & & Đã có \\
\hline \multirow[t]{3}{*}{4} & \multirow[t]{3}{*}{$\begin{array}{l}\text { Phương } \\
\text { pháp học } \\
\text { đại học }\end{array}$} & $\begin{array}{l}\text { Practicing } \\
\text { College } \\
\text { Learning } \\
\text { Strategies }\end{array}$ & Hopper C. & $\begin{array}{l}\text { Houghton } \\
\text { Mifflin, New } \\
\text { York. }\end{array}$ & 2004 & & $\begin{array}{l}\text { Chưa } \\
\text { có tại } \\
\text { Khoa }\end{array}$ \\
\hline & & $\begin{array}{l}\text { How to Study in } \\
\text { College }\end{array}$ & Paul W. & $\begin{array}{l}\text { Houghton } \\
\text { Mifflin, New } \\
\text { York. }\end{array}$ & 2005 & & $\begin{array}{l}\text { Chưa } \\
\text { có }\end{array}$ \\
\hline & & $\begin{array}{l}\text { Essential } \\
\text { Managers - } \\
\text { Making } \\
\text { presentations }\end{array}$ & Tim Hindle & $\begin{array}{l}\text { Dorling } \\
\text { Kindersley } \\
\text { Limited. } \\
\text { London. }\end{array}$ & 1998 & & $\begin{array}{l}\text { Chưa } \\
\text { có }\end{array}$ \\
\hline \multirow[t]{3}{*}{5} & \multirow{3}{*}{$\begin{array}{l}\text { Nhập môn } \\
\text { khu vực học } \\
\text { và Việt Nam } \\
\text { học }\end{array}$} & $\begin{array}{l}\text { Khu vực học và } \\
\text { Nhập môn Việt } \\
\text { Nam học học. }\end{array}$ & Trần Lê Bảo & $\begin{array}{c}\text { Giáo Dục, Hà } \\
\text { Nội }\end{array}$ & 2008 & & Đã có \\
\hline & & $\begin{array}{l}\text { Về cách tiếp cận } \\
\text { khu vực học }\end{array}$ & $\begin{array}{l}\text { Phạm Đức } \\
\text { Thành }\end{array}$ & \begin{tabular}{|l} 
Tapr chí \\
Nghiên cứu \\
Đông Nam Á
\end{tabular} & $\begin{array}{l}\text { số } \\
1 / 2001 .\end{array}$ & & Đã có \\
\hline & & $\begin{array}{l}\text { Văn hoá vùng và } \\
\text { phân vùng văn }\end{array}$ & $\begin{array}{l}\text { Ngô Đức Thịnh } \\
\text { (chủ biên): }\end{array}$ & $\mathrm{KHXH}$ & 1993 & & Đã có \\
\hline
\end{tabular}




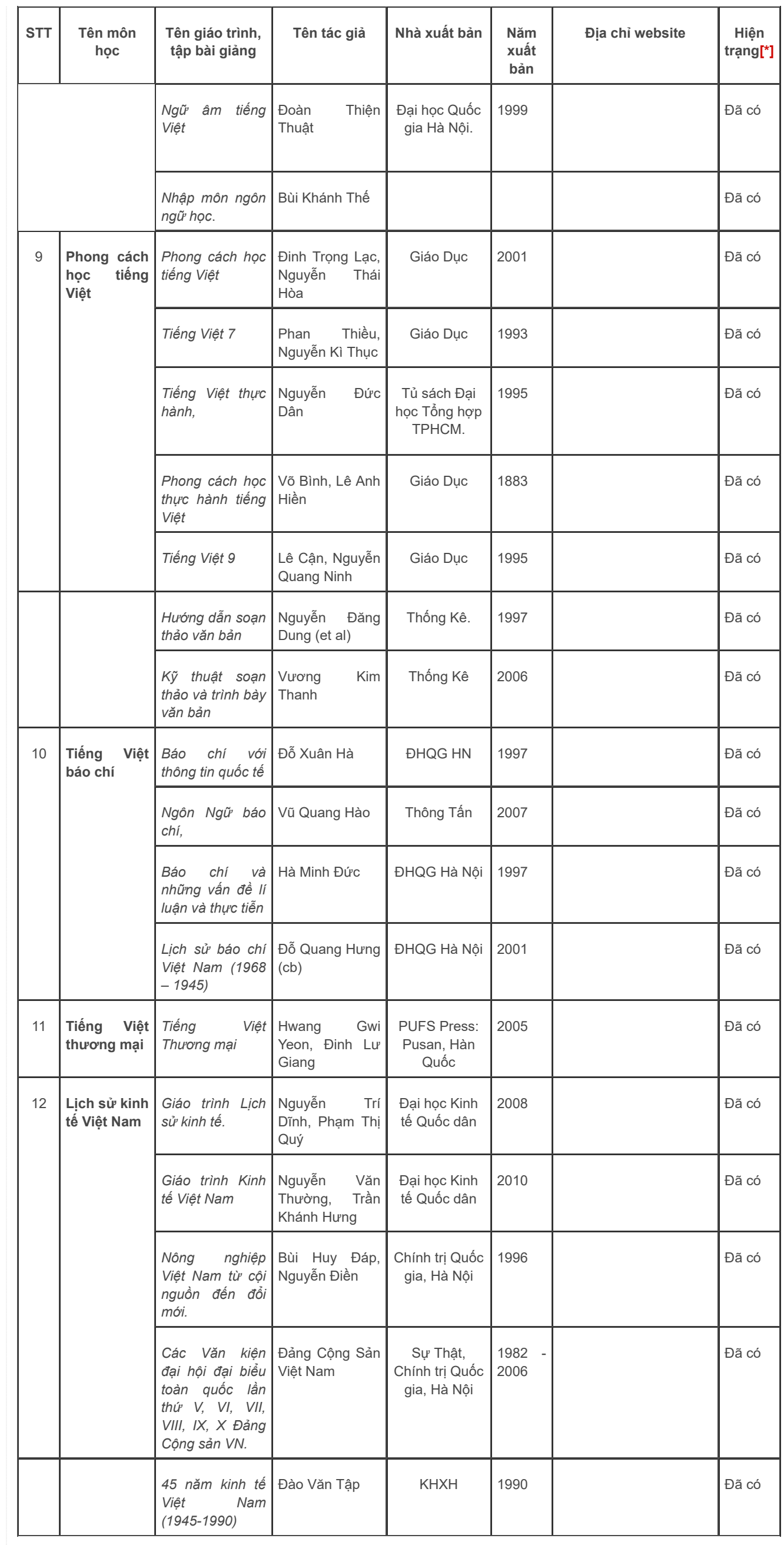




\begin{tabular}{|c|c|c|c|c|c|c|c|}
\hline STT & $\begin{array}{c}\text { Tên môn } \\
\text { học }\end{array}$ & $\begin{array}{l}\text { Tên giáo trình, } \\
\text { tập bài giảng }\end{array}$ & Tên tác giả & Nhà xuất bản & $\begin{array}{c}\text { Năm } \\
\text { xuất } \\
\text { bản }\end{array}$ & Địa chỉ website & $\begin{array}{c}\text { Hiện } \\
\text { trạng[*] }\end{array}$ \\
\hline & & $\begin{array}{l}\text { Đến với Lịch sử } \\
\text { Văn hoá Việt } \\
\text { Nam }\end{array}$ & Hà Văn Tấn & Hôi Nhà Văn. & 2005 & & Đã có \\
\hline & & $\begin{array}{l}\text { Các nền văn cổ } \\
\text { ở Việt Nam }\end{array}$ & $\begin{array}{l}\text { Hoàng Xuân } \\
\text { Chinh }\end{array}$ & $\begin{array}{l}\text { Lao Động, Hà } \\
\text { Nội. }\end{array}$ & 2005 & & Đã có \\
\hline & & $\begin{array}{l}\text { Dấu tích văn } \\
\text { hoá thời Nguyễn }\end{array}$ & Hồ Vĩnh & Thuận Hoá. & 2000 & & Đã có \\
\hline & & $\begin{array}{l}\text { Di tích gốm cổ } \\
\text { Bình Định: mảnh } \\
\text { gốm và sản } \\
\text { phẩm gốm liên } \\
\text { quan, }\end{array}$ & $\begin{array}{l}\text { Kerry Nguyễn } \\
\text { Long }\end{array}$ & $\begin{array}{l}\text { Khảo cổ học, } \\
\text { số 3-1998, } \\
\text { tr.101- 111. }\end{array}$ & 1998 & & Đã có \\
\hline & & $\begin{array}{l}\text { Tìm hiểu lịch sử } \\
\text { kiến trúc tháp } \\
\text { Champa }\end{array}$ & Lê Đình Phụng & $\begin{array}{c}\text { Văn hoá } \\
\text { Thông tin \& } \\
\text { Viện Văn Hoá }\end{array}$ & 2005 & & Đã có \\
\hline & & $\begin{array}{l}\text { Nghệ thuật Phật } \\
\text { giáo và Hindu } \\
\text { giáo ở đồng } \\
\text { bằng sông Cửu } \\
\text { Long trước thế } \\
\text { kỷX }\end{array}$ & Lê Thị Liên & Thế Giới. & 2006 & & Đã có \\
\hline & & $\begin{array}{l}\text { Khảo cổ Đồng } \\
\text { Nai thời tiền sử }\end{array}$ & $\begin{array}{l}\text { Lê Xuân Diệm, } \\
\text { Phạm Quang } \\
\text { Sơn, Bùi Chí } \\
\text { Hoàng }\end{array}$ & Đồng Nai & 1991 & & Đã có \\
\hline & & $\begin{array}{l}\text { Văn Hoá Óc Eo } \\
- \text { Những khám } \\
\text { phá mới }\end{array}$ & $\begin{array}{l}\text { Lê Xuân Diệm, } \\
\text { Đào Linh Côn, } \\
\text { Võ Sĩ Khải }\end{array}$ & Hà Nội & 1995 & & Đã có \\
\hline & & $\begin{array}{l}\text { Vương Quốc } \\
\text { Champa }\end{array}$ & Lương Ninh & $\begin{array}{c}\text { Đại học Quốc } \\
\text { gia Hà Nội. }\end{array}$ & 2006 & & Đã có \\
\hline & & Nước Phù Nam & Lương Ninh & $\begin{array}{c}\text { Đại học Quốc } \\
\text { gia TPHCM }\end{array}$ & 2006 & & Đã có \\
\hline & & $\begin{array}{l}\text { Văn hoá cổ } \\
\text { Champa }\end{array}$ & Ngô Văn Doanh & Trả & 2002 & & Đã có \\
\hline & & $\begin{array}{l}\text { Thánh địa Mỹ } \\
\text { Sơn }\end{array}$ & Ngô Văn Doanh & Trẻ & 2003 & & Đã có \\
\hline & & $\begin{array}{l}\text { Văn hoá và cur } \\
\text { dân đồng bằng } \\
\text { sông Cửu Long }\end{array}$ & $\begin{array}{ll}\text { Nguyễn } & \text { Công } \\
\text { Bình, Lê } & \text { Xuân } \\
\text { Diệm, } & \text { Mạc } \\
\text { Đường } & \end{array}$ & $\begin{array}{l}\text { Khoa học Xã } \\
\text { hội, Hà Nội. }\end{array}$ & 1990 & & Đã có \\
\hline \multirow[t]{6}{*}{17} & $\begin{array}{lr}\text { Văn } & \text { hoá } \\
\text { Đông } & \text { Nam } \\
\text { Á } & \end{array}$ & $\begin{array}{l}\text { Văn minh Đông } \\
\text { Nam Á }\end{array}$ & $\begin{array}{l}\text { Đinh Trung Kiên } \\
\text { 2006, }\end{array}$ & $\begin{array}{l}\text { Quân đội } \\
\text { Nhân dân. }\end{array}$ & 2006 & $\begin{array}{l}\text { vi.wikipedia.org, } \\
\text { khoahoc.com.vn }\end{array}$ & Đã có \\
\hline & & $\begin{array}{l}\text { Lịch sưr văn } \\
\text { minh thế giới }\end{array}$ & $\begin{array}{l}\text { Vũ Dương Ninh } \\
\text { (chủ biên) }\end{array}$ & Giáo Dục & 2000 & sfa-antiques.com & Đã có \\
\hline & & $\begin{array}{l}\text { The Art of } \\
\text { Southeast Asia }\end{array}$ & Philip Rawson & $\begin{array}{c}\text { Frederick A. } \\
\text { Praeger, New } \\
\text { York. } \\
\text { Washington. }\end{array}$ & 1967 & & $\begin{array}{c}\text { Chưa } \\
\text { có }\end{array}$ \\
\hline & & $\begin{array}{l}\text { Di sản thế giới, } \\
\text { tập 1: Châu Á }\end{array}$ & Bùi Đẹp & Trẻ & 1999 & & Đã có \\
\hline & & $\begin{array}{l}\text { Di sản thế giới, } \\
\text { tập 2: Châu Á }\end{array}$ & Bùi Đẹp & Trẻ & 1999 & & Đã có \\
\hline & & $\begin{array}{l}\text { Di sản thế giới, } \\
\text { tập 10: Châu Á }\end{array}$ & Bùi Đẹp & Trẻ & 2004 & & Đã có \\
\hline
\end{tabular}

giáo ở

Long trước thế

Khảo cổ Đồng Lê Xuân Diệm, Đồng Nai 1991 


\begin{tabular}{|c|c|c|c|c|c|c|c|}
\hline STT & $\begin{array}{c}\text { Tên môn } \\
\text { học }\end{array}$ & $\begin{array}{l}\text { Tên giáo trình, } \\
\text { tập bài giảng }\end{array}$ & Tên tác giả & Nhà xuất bản & $\begin{array}{l}\text { Năm } \\
\text { xuất } \\
\text { bản }\end{array}$ & Địa chỉ website & $\begin{array}{c}\text { Hiện } \\
\text { trạng[] }\end{array}$ \\
\hline & & bổ sung & & & & & \\
\hline & & $\begin{array}{l}\text { Nghệ thuật } \\
\text { Đông Nam Á }\end{array}$ & $\begin{array}{l}\text { Cao Xuân Phổ } \\
\text { (chủ biên) }\end{array}$ & $\begin{array}{c}\text { Viện Đông } \\
\text { Nam Á, Hà } \\
\text { Nội. }\end{array}$ & 1984 & & Đã có \\
\hline & & $\begin{array}{l}\text { Di sản thế giới ở } \\
\text { Việt Nam } 2005\end{array}$ & & $\begin{array}{l}\text { Trung tâm } \\
\text { công nghệ } \\
\text { Thông tin du } \\
\text { lịch }\end{array}$ & 2005 & & Đã có \\
\hline & & $\begin{array}{l}\text { Điêu } \quad \text { Khắc } \\
\text { Chàm }\end{array}$ & & $\begin{array}{l}\text { Khoa học Xã } \\
\text { hội, Hà Nội. }\end{array}$ & 1988 & & Đã có \\
\hline & & $\begin{array}{|lr|}\text { Cham art - } \\
\text { Treasures from } \\
\text { the Da Nang } \\
\text { Museum, } \\
\text { Vietnam, r } \\
\text { Thames } \\
\text { Hudson, London }\end{array}$ & $\begin{array}{l}\text { Emmanuel } \\
\text { Guillon }\end{array}$ & & 2001 & & Đã có \\
\hline & & Ancient Angkor & $\begin{array}{l}\text { Michael } \\
\text { Freeman and } \\
\text { Claude Jacques }\end{array}$ & $\begin{array}{l}\text { River Books, } \\
\text { Bangkok, } \\
\text { Thailan. }\end{array}$ & 2005 & & $\begin{array}{l}\text { Chưa } \\
\text { có }\end{array}$ \\
\hline & & $\begin{array}{l}\text { Về Khảo cổ học } \\
\text { Tiền sử Đông } \\
\text { Nam Á }\end{array}$ & $\begin{array}{l}\text { Hà Văn Tấn } \\
\text { (chủ biên) }\end{array}$ & $\begin{array}{l}\text { Viện Đông } \\
\text { Nam Á, Hà } \\
\text { Nội. }\end{array}$ & 1983 & & $\begin{array}{l}\text { Chưa } \\
\text { có }\end{array}$ \\
\hline & & $\begin{array}{l}\text { Văn hoá Đông } \\
\text { Sơn ở Việt Nam }\end{array}$ & $\begin{array}{l}\text { Hà Văn Tấn } \\
\text { (chủ biên) }\end{array}$ & $\begin{array}{l}\text { Khoa học Xã } \\
\text { hội, Hà Nội }\end{array}$ & 1994 & & $\begin{array}{l}\text { Chưa } \\
\text { có }\end{array}$ \\
\hline & & $\begin{array}{l}\text { Đông Nam Á sử } \\
\text { lược }\end{array}$ & D.G. E. Hall & $\begin{array}{c}\text { Nhà sách Khai } \\
\text { Trí. }\end{array}$ & 1968 & & Đã có \\
\hline & & $\begin{array}{l}\text { The bronze Age } \\
\text { of } \quad \text { Southeast } \\
\text { Asia }\end{array}$ & Charles Higham & $\begin{array}{l}\text { Cambridge } \\
\text { University } \\
\text { Press. }\end{array}$ & 1996 & & $\begin{array}{l}\text { Chưa } \\
\text { có }\end{array}$ \\
\hline & & $\begin{array}{l}\text { Các nền văn cổ } \\
\text { ở Việt Nam }\end{array}$ & $\begin{array}{l}\text { Hoàng Xuân } \\
\text { Chinh }\end{array}$ & $\begin{array}{c}\text { Lao Động, Hà } \\
\text { Nội. }\end{array}$ & 2005 & & Đã có \\
\hline & & $\begin{array}{ll}\text { The Art of } \\
\text { Champa, } & \text { La } \\
\text { Renaissance } & d u \\
\text { livre. } & \end{array}$ & $\begin{array}{l}\text { Jean-Francois } \\
\text { Hubert }\end{array}$ & & 2005 & & $\begin{array}{l}\text { Chưa } \\
\text { có }\end{array}$ \\
\hline & & $\begin{array}{l}\text { Lịch sủ các } \\
\text { nước ASEAN }\end{array}$ & $\begin{array}{l}\text { Khắc Thành, } \\
\text { Sanh Phúc }\end{array}$ & Trẻ. & 2001 & & $\begin{array}{l}\text { Chưa } \\
\text { có }\end{array}$ \\
\hline & & $\begin{array}{l}\text { Lịch sử Mỹ thuật } \\
\text { Viễn Đông }\end{array}$ & $\begin{array}{l}\text { Sherman E. } \\
\text { Lee ; biên dịch : } \\
\text { Trần Văn Huân }\end{array}$ & Mỹ Thuật. & 2007 & & $\begin{array}{l}\text { Chưa } \\
\text { có }\end{array}$ \\
\hline & & $\begin{array}{l}\text { Nghệ thuật Phật } \\
\text { giáo và Hindu } \\
\text { giáo ở đồng } \\
\text { bằng sông Cứu } \\
\text { Long trước thế } \\
\text { kỷX }\end{array}$ & Lê Thị Liên & Thế Giới. & 2006 & & $\begin{array}{l}\text { Chưa } \\
\text { có }\end{array}$ \\
\hline & & $\begin{array}{l}\text { Vương Quốc } \\
\text { Champa, }\end{array}$ & Lương Ninh & $\begin{array}{c}\text { Đại học Quốc } \\
\text { gia Hà Nội }\end{array}$ & 2006 & & Đã có \\
\hline & & $\begin{array}{l}\text { Lịch sưr Đông } \\
\text { Nam Á }\end{array}$ & $\begin{array}{l}\text { Lương Ninh } \\
\text { (chủ biên) }\end{array}$ & Giáo Dục. & 2005 & & Đã có \\
\hline & & $\begin{array}{l}\text { Danh thắng và } \\
\text { Kiến trúc Đông } \\
\text { Nam Á }\end{array}$ & Ngô Văn Doanh & $\begin{array}{c}\text { Văn hoá } \\
\text { Thông tin, Hà } \\
\text { Nội. }\end{array}$ & 1998 & & Đã có \\
\hline
\end{tabular}




\begin{tabular}{|c|c|c|c|c|c|c|c|}
\hline STT & $\begin{array}{c}\text { Tên môn } \\
\text { học }\end{array}$ & $\begin{array}{l}\text { Tên giáo trình, } \\
\text { tập bài giảng }\end{array}$ & Tên tác giả & Nhà xuất bản & $\begin{array}{l}\text { Năm } \\
\text { xuất } \\
\text { bản }\end{array}$ & Địa chỉ website & $\begin{array}{c}\text { Hiện } \\
\text { trạng[*] }\end{array}$ \\
\hline & & $\begin{array}{l}\text { Nghệ thuật } \\
\text { Đông Nam Á }\end{array}$ & $\begin{array}{ll}\text { Ngô } & \text { Văn } \\
\text { Doanh, } & \text { Cao } \\
\text { Xuân Phổ, } & \text { Trần } \\
\text { Thị Lý } & \end{array}$ & Lao Động. & 2000 & & Đã có \\
\hline & & $\begin{array}{l}\text { Văn hoá cổ } \\
\text { Champa }\end{array}$ & Ngô Văn Doanh & Trẻ & 2002 & & Đã có \\
\hline & & $\begin{array}{l}\text { Những nền mỹ } \\
\text { thuật } \quad \text { ngoài } \\
\text { Phương Tây }\end{array}$ & $\begin{array}{|ll|}\text { Michael } & \\
\text { Kampen } & \text { Oriley; } \\
\text { Phan } & \text { Quang } \\
\text { Định biên dịch }\end{array}$ & Mỹ Thuật. & 2005 & & $\begin{array}{l}\text { Chưa } \\
\text { có }\end{array}$ \\
\hline & & $\begin{array}{l}\text { Quần thể di tích } \\
\text { Huế }\end{array}$ & Phan Thuận An & Trẻ & 2005 & & $\begin{array}{l}\text { Chưa } \\
\text { có }\end{array}$ \\
\hline & & $\begin{array}{l}\text { Về Lịch sử Đông } \\
\text { Nam Á thời cổ }\end{array}$ & $\begin{array}{l}\text { Phạm Nguyên } \\
\text { Long (chủ biên) }\end{array}$ & $\begin{array}{c}\text { Viện Đông } \\
\text { Nam Á, Hà } \\
\text { Nội }\end{array}$ & 1983 & & Đã có \\
\hline & & $\begin{array}{l}\text { The Plain of Jars } \\
- \text { A Guide Book, } \\
\text { Vientiane, Lào. }\end{array}$ & $\begin{array}{l}\text { Bounmy } \\
\text { Thepsimuong }\end{array}$ & & 2004 & & $\begin{array}{l}\text { Chưa } \\
\text { có }\end{array}$ \\
\hline & & $\begin{array}{l}\text { Việt Nam Đông } \\
\text { Nam Á- Quan hệ } \\
\text { lịch sử văn hoá }\end{array}$ & $\begin{array}{l}\text { Viện nghiên cứu } \\
\text { Đông Nam Á }\end{array}$ & $\begin{array}{l}\text { Chính trị Quốc } \\
\text { gia, Hà Nội. }\end{array}$ & 1995 & & Đã có \\
\hline \multirow[t]{3}{*}{18} & 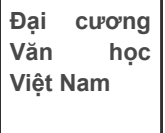 & $\begin{array}{l}\text { Lịch sử văn học } \\
\text { Việt Nam tập } 1, \\
\text { tập } 2\end{array}$ & $\begin{array}{lr}\text { Đinh r } & \text { Gia } \\
\text { Khánh, Bùi Duy } \\
\text { Tân, Mai } & \text { Cao } \\
\text { Chương } & \end{array}$ & $\begin{array}{l}\text { Đại học \& } \\
\text { Trung học } \\
\text { chuy ên } \\
\text { nghiệp }\end{array}$ & 1978 & & Đã có \\
\hline & & $\mid \begin{array}{lll}\text { Đă̆c } & \text { điểm lịch sử } \\
\text { văn } & \text { học } & \text { Việt } \\
\text { Nam } & & \end{array}$ & Lê Trí Viễn & $\begin{array}{c}\text { Đại học \& } \\
\text { Trung học } \\
\text { chuyên nghiệp }\end{array}$ & 1976 & & Đã có \\
\hline & & $\begin{array}{l}\text { Ngữ văn } 10, \text { tập } \\
1\end{array}$ & & Giáo dục & 2008 & & Đã có \\
\hline \multirow[t]{3}{*}{19} & $\begin{array}{lr}\text { Đại } & \text { cương } \\
\text { Văn } & \text { học } \\
\text { Việt } & \text { Nam }\end{array}$ & $\begin{array}{l}\text { Lịch sử văn học } \\
\text { Việt Nam tập } 1 \text {, } \\
\text { tập } 2\end{array}$ & 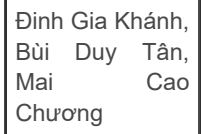 & $\begin{array}{c}\text { Đại học \& } \\
\text { Trung học } \\
\text { chuyên nghiệp }\end{array}$ & 1978 & & Đã có \\
\hline & & $\begin{array}{l}\text { Đặc điểm lịch sử } \\
\text { văn học Việt } \\
\text { Nam }\end{array}$ & Lê Trí Viễn & $\begin{array}{c}\text { Đại học \& } \\
\text { Trung học } \\
\text { chuyên nghiệp }\end{array}$ & 1976 & & Đã có \\
\hline & & $\begin{array}{l}\text { Ngữ văn 11, 12, } \\
\text { tập } 1\end{array}$ & & Giáo dục & 2008 & & Đã có \\
\hline \multirow[t]{5}{*}{20} & $\begin{array}{l}\text { Liên kết và } \\
\text { soạn thảo } \\
\text { văn bản } \\
\text { tiếng Việt }\end{array}$ & $\begin{array}{l}\text { Các bình diện } \\
\text { của từ và tùr } \\
\text { tiếng Việt }\end{array}$ & Đỗ Hữu Châu & ĐHQG, HN. & 1997 & & Đã có \\
\hline & & $\begin{array}{l}\text { Để viết đúng } \\
\text { tiếng Việt }\end{array}$ & $\begin{array}{l}\text { Nguyễn Khánh } \\
\text { Nồng }\end{array}$ & Trẻ & 2006 & & Đã có \\
\hline & & $\begin{array}{l}\text { Để viết tiếng } \\
\text { Việt thật hay }\end{array}$ & $\begin{array}{l}\text { Nguyễn Khánh } \\
\text { Nồng }\end{array}$ & Trẻ & 2006 & & Đã có \\
\hline & & $\begin{array}{l}\text { Tiếng Việt thực } \\
\text { hành }\end{array}$ & $\begin{array}{ll}\begin{array}{l}\text { Nguyễn } \\
\text { Thuyết } \\
\text { biên) }\end{array} & \text { Minh } \\
\text { (chủ }\end{array}$ & ĐHQG HN. & 1997 & & Đã có \\
\hline & & $\begin{array}{l}\text { Hệ thống liên kết } \\
\text { văn bản tiếng } \\
\text { Việt }\end{array}$ & $\begin{array}{l}\text { Trần } \quad \text { Ngọc } \\
\text { Thêm }\end{array}$ & $\mathrm{KHXH}, \mathrm{HN}$. & 1985 & & Đã có \\
\hline
\end{tabular}




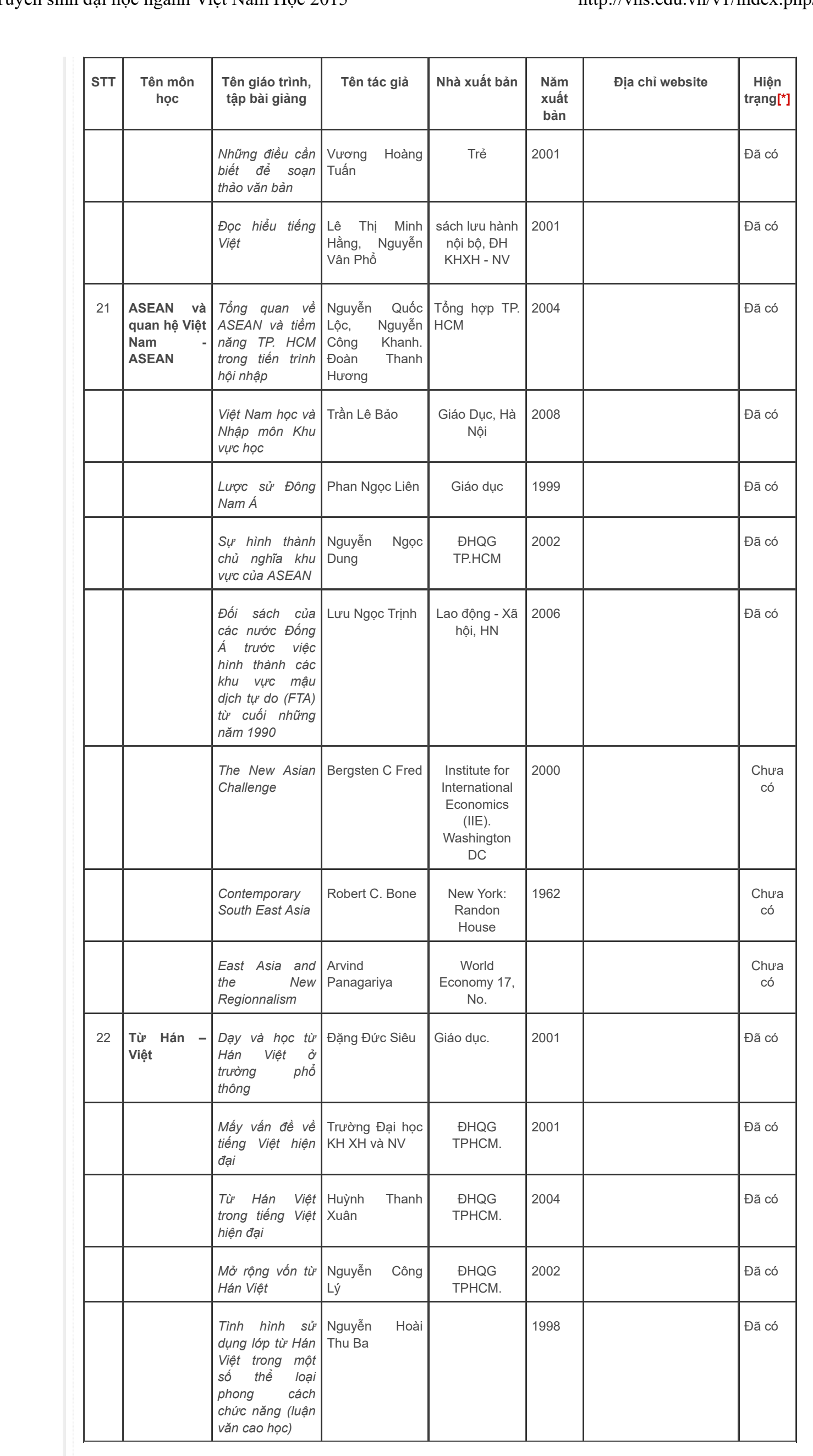

http://vns.edu.vn/v1/index.php/en/vietnamese-studies/undergraduate-p..

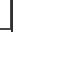




\begin{tabular}{|c|c|c|c|c|c|c|c|}
\hline STT & $\begin{array}{l}\text { Tên môn } \\
\text { học }\end{array}$ & $\begin{array}{l}\text { Tên giáo trình, } \\
\text { tập bài giảng }\end{array}$ & Tên tác giả & Nhà xuất bản & $\begin{array}{l}\text { Năm } \\
\text { xuất } \\
\text { bản }\end{array}$ & Địa chỉ website & $\begin{array}{c}\text { Hiện } \\
\text { trạng[] }\end{array}$ \\
\hline & & $\begin{array}{l}\text { Nguồn gôc và } \\
\text { quá trình hình } \\
\text { thành cách đọc } \\
\text { Hán Việt }\end{array}$ & Nguyễn Tài Cẩn & $\mathrm{KHXH}$ & 1979 & & Đã có \\
\hline & & $\begin{array}{l}\text { Mẹo giải nghĩa } \\
\text { từ Hán Việt }\end{array}$ & Phan Ngọc & Thanh Niên & 2000 & & Đã có \\
\hline & & $\begin{array}{l}\text { Một số nhận xét } \\
\text { về tri thức và xu } \\
\text { hướng sử dụng } \\
\text { từ Hán Việt ở } \\
\text { học sinh, sinh } \\
\text { viên hiện nay } \\
\text { (luận văn cao } \\
\text { học). }\end{array}$ & $\mid \begin{array}{lll}\text { Trần } & \text { Thi Kim } \\
\text { Anh } & & \end{array}$ & & 1999 & & Đã có \\
\hline & & $\begin{array}{l}\text { Giải thích các từ } \\
\text { gần âm, gần } \\
\text { nghĩa dễ nhầm } \\
\text { lẫn }\end{array}$ & Trương Chính & Giáo dục. & 1997 & & Đã có \\
\hline \multirow[t]{7}{*}{23} & \begin{tabular}{|l|} 
Lịch \\
tiếng Việt
\end{tabular} & $\begin{array}{l}\text { Sự biến hoá của } \\
\text { âm tắc giữa } \\
\text { (obstruentes } \\
\text { mediales) trong } \\
\text { tiếng Việt }\end{array}$ & M. Ferlus & Tc Ngôn ngữ & $2 / 1997$ & en.wikipedia.org & Đã có \\
\hline & & $\begin{array}{l}\text { Về sự phân loại } \\
\text { các ngôn ngữ ờ } \\
\text { Đông Nam châu } \\
\text { Á }\end{array}$ & S.E. Jakhontov & Tc Ngôn ngữ & $1 / 1991$ & & Đã có \\
\hline & & $\begin{array}{l}\text { Phương ngữ học } \\
\text { tiếng Việt }\end{array}$ & Hoàng Thị Châu & ĐHGQ HN & 2004 & & Đã có \\
\hline & & $\begin{array}{l}\text { Tìm hiểu tiếng } \\
\text { Việt lịch sử }\end{array}$ & $\begin{array}{l}\text { Nguyễn Ngọc } \\
\text { San }\end{array}$ & ĐHSP, HN & 2003 & & Đã có \\
\hline & & $\begin{array}{l}\text { Giáo trình lịch } \\
\text { sử Ngữ âm tiếng } \\
\text { Việt (sơ thảo) }\end{array}$ & Nguyễn Tài Cẩn & Giáo Dục & 1995 & & Đã có \\
\hline & & $\begin{array}{l}\text { Nguồn gốc và } \\
\text { quá 1trinh hình } \\
\text { thành cách đọc } \\
\text { Hán - Việt }\end{array}$ & Nguyễn Tài Cẩn & ĐHQG HN & 2001 & & Đã có \\
\hline & & $\begin{array}{l}\text { Giáo trình lịch } \\
\text { sử tiếng Việt (so' } \\
\text { thảo) }\end{array}$ & Trần Trí Dõi & ĐHQG HN & 2005 & & Đã có \\
\hline \multirow[t]{5}{*}{24} & 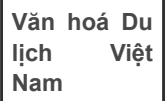 & \begin{tabular}{|lr} 
Du Lịch & Ba \\
Miền: & Đất \\
Phương & Nam.
\end{tabular} & Ngôn Bửu & Trẻ, TPHCM & 1998 & $\begin{array}{l}\text { Tuoitre.com.vn, } \\
\text { sggp.com.vn, }\end{array}$ & Đã có \\
\hline & & $\begin{array}{lll}\text { Đất Việt } & \text { Mến } \\
\text { Yêu: } & \text { Những } & \text { Nẻo } \\
\text { Đường } & \text { Việt } \\
\text { Nam. } & \end{array}$ & Phạm, Côn Sơn & Đồng Nai & 1998 & $\begin{array}{l}\text { sgtt.com.vn, } \\
\text { vietnamtourism.org }\end{array}$ & Đã có \\
\hline & & $\begin{array}{ll}\text { Hosts and } \\
\text { Guests: The } \\
\text { Anthropology of } \\
\text { Tourism }\end{array}$ & Smith, Valene L. & $\begin{array}{l}\text { University of } \\
\text { Pennsylvania } \\
\text { Press }\end{array}$ & 1997 & & Đã có \\
\hline & & $\begin{array}{l}\text { Du lịch và Du } \\
\text { lịch Sinh Thái. }\end{array}$ & Thế Đạt & $\begin{array}{l}\text { Lao Động, Hà } \\
\text { Nội }\end{array}$ & 2003 & & Đã có \\
\hline & & $\begin{array}{l}\text { Du lịch Văn Hoá } \\
\text { ở Việt Nam }\end{array}$ & $\begin{array}{l}\text { Thu Trang Công } \\
\text { Thị Nghĩa, }\end{array}$ & Trẻ, TPHCM & 2001 & & Đã có \\
\hline 25 & $\begin{array}{l}\text { Tiến r trình } \\
\text { lịch sử Việt } \\
\text { Nam }\end{array}$ & $\begin{array}{l}\text { Tiến trình lịch sử } \\
\text { Việt Nam (Giáo } \\
\text { trình) }\end{array}$ & $\begin{array}{l}\text { Nguyễn Quang } \\
\text { Ngọc (chủ biên) }\end{array}$ & Nxb. Giáo dục & 2003 & & Đã có \\
\hline
\end{tabular}




\begin{tabular}{|c|c|c|c|c|c|c|c|c|}
\hline STT & $\begin{array}{l}\text { Tên môn } \\
\text { học }\end{array}$ & $\begin{array}{l}\text { Tên giáo trình, } \\
\text { tập bài giảng }\end{array}$ & Tên tác & c giả & Nhà xuất bản & $\begin{array}{l}\text { Năm } \\
\text { xuất } \\
\text { bản }\end{array}$ & Địa chỉ website & $\begin{array}{l}\text { Hiện } \\
\text { trạng[*] }\end{array}$ \\
\hline 26 & $\begin{array}{ll}\text { Ngôn } & \text { ngũ̃ } \\
\text { học } & \text { đối } \\
\text { chiếu } & \end{array}$ & $\begin{array}{l}\text { Nghiên cứu đối } \\
\text { chiếu các ngôn } \\
\text { ngữ (Sách tham } \\
\text { khảo) }\end{array}$ & $\begin{array}{l}\text { Lê } \\
\text { Thiêm. }\end{array}$ & Quang & NxbĐHQG HN & 2004 & & \\
\hline 27 & $\begin{array}{l}\text { Phương } \\
\text { pháp giảng } \\
\text { dạy ngoại } \\
\text { ngữ }\end{array}$ & 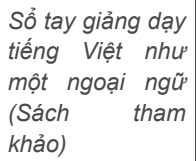 & $\begin{array}{l}\text { Phan } \\
\text { Giưỡng }\end{array}$ & Văn & $\begin{array}{l}\text { Nxb Văn hoá } \\
\text { Sài Gòn }\end{array}$ & 2009 & & \\
\hline
\end{tabular}

\section{Hướng dẫn thực hiện chương trình}

Trên đây là toàn bộ chương trình đào tạo, phương tiện giảng dạy, những mối quan hệ cộng tác với các đơn vị liên quan đến việc đào tạo sinh viên ngành Việt Nam học bậc Đại học hệ chính quy.

Chương trình này được áp dụng cho sinh viên bậc Đại học hệ chính quy ngành Việt Nam học kể từ khoá 2013 về sau. Ban Chủ nhiệm, Giáo vụ Khoa Việt Nam học triển khai thực hiện trên cơ sở căn cứ vào các Quy chế liên quan về giáo dục đào tạo của Hiệu trưởng Trường Đại học Khoa học Xã hội - Nhân văn, Đại học Quốc gia Thành phố Hồ Chí Minh, của Bộ Giáo dục và Đào tạo.

HIẸU TRƯỞNG

TRƯỞNG KHOA

Chủ tịch HĐKH\&ĐT Khoa VNH

PGS.TS. Võ Văn Sen

PGS.TS. Lê Khắc Cường

1 Quy ước Không nhấn mạnh Rất nhấn mạnh

Có nhấn mạnh Đặc biệt nhấn mạnh

2 Chỉ dành cho sinh viên Việt Nam, theo hình thức tự tích luỹ. Khi xét tốt nghiêp, sinh viên nôp chứng ch ngoại ngữ $B$ của một trong các ngoại ngữ sau: Anh, Nga, Pháp, Trung, Đức, Nhật, Hàn, Tây Ban Nha, Ý theo quy định chung của Trường. Sinh viên là Việt kiều và người nước ngoài thì tiếng Việt được xem là ngoại ngữ 2 và đã được tích hợp vào các môn học, đặc biệt là các môn tiếng Việt kỹ năng theo Quy chế quản lý nguò̀i nước ngoài hoc tập tại Việt Nam ban hành kèm theo Thông tư số o3/2014/TT-BGDĐT ngày 25 tháng 02 năm 2014 của Bộ trưởng Bô Giáo dục và Đào tạo.

5 Khoá luận tốt nghiệp: Dành cho những sinh viên có đủ điều kiện về điểm (điểm trung bình tích luỹ toàn khoá từ 7,5 điểm trở lên ) và có nguyện vọng làm khoá luận. Những sinh viên này được miễn 10 tín chỉ thuộc các học phần tự chọn (chỉ học 130 tín chỉ). Nếu khoá luận được đánh giá từ đạt (5 điểm) trở lên, sinh viên sẽ được xét cấp bằng tốt nghiệp.

[] Đã có hoặc chưa có tại Khoa đối với giáo trình, tập bài giảng

Home $\gg$ Vietnamese studies $\gg$ Undergraduate Program \C Course Exam Results $>$ Tuyển sinh đại học ngành Việt Nam Học 2015
Phonetic lab
Đối tác quốc tế
Contact Us
News
Resources \& Text Books
Service Center
VNS Clubs
Gallery
Media
Job Vacancies

Copyright $\odot 2012$ Department of Vietnamese Studies in University of Social Sciences \& Humanities 10 - 12 Dinh Tien Hoang Street, District 1, Ho Chi Minh City

Tel: +84 2838 225009; Fax: + 8428 38229390; Email: vietnamhoc@vns.edu.vn - vietnamhoc@hcmussh.edu.vn 


\section{Tài liệu tham khảo:}

Đinh Gia Khánh, Bùi Duy Tân, Mai Cao Chương. (1978). Lịch sử văn học Việt Nam. Nxb Đại học \& Trung học chuyên nghiệp, Hà Nội.

Phạm Minh Chính, Vương Quân Hoàng. (2009). Kinh tế Việt Nam: Thăng trầm và đột phá. Nxb Chính trị Quốc gia, Hà Nội.

Trần Lê Bảo. (2008). Việt Nam học và nhập môn khu vực học. Nxb Giáo dục, Hà Nội. 